
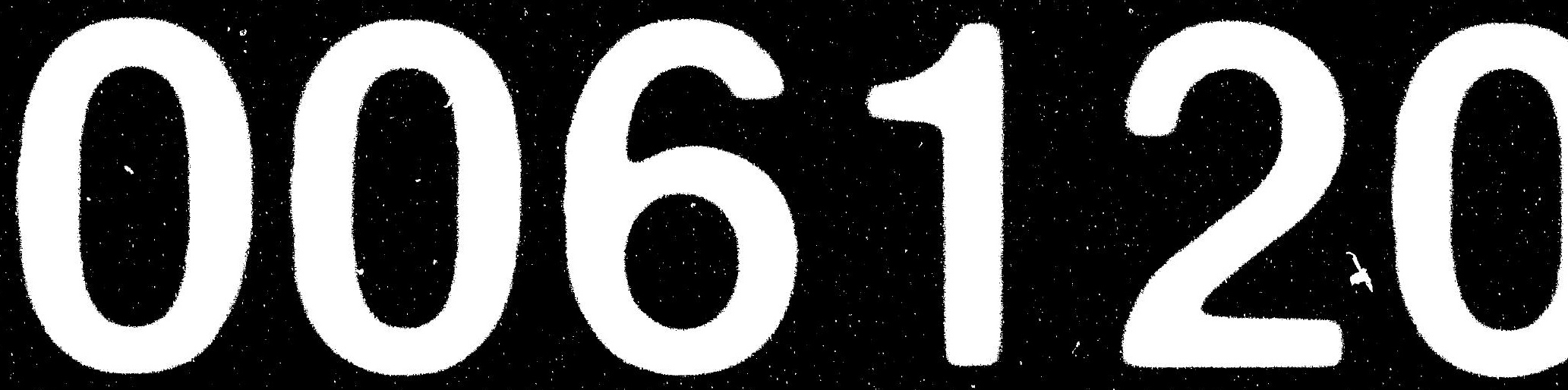

$\iint_{0}$

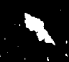

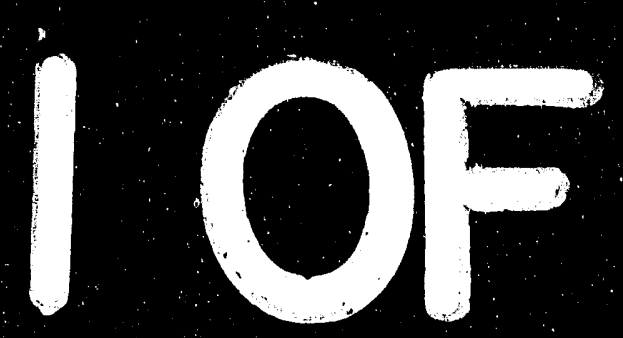

1

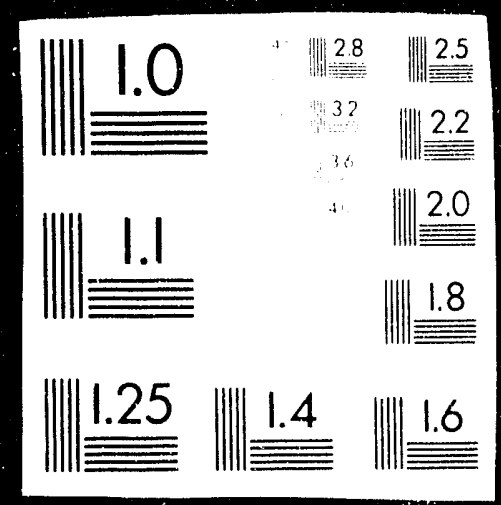




\section{International Oil Supplies and Demands}

Energy Modeling Forum Stanford University

Stanford, California 94305 


\title{
International Oil Supplies and Demands
}

\author{
DISCLAIMER
}

This report was prepared as an account of work sponsored by an agency of the United States Government. Neither the United States Government nor any agency thereof, nor any of their employees, makes any warranty, express or implied, or assumes any legal liability or responsibility for the accuracy, completeness, or usefulness of any information, apparatus, product, or process disclosed, or represents that its use would not infringe privately owned rights. Reference herein to any specific commercial product, process, or service by trade name, trademark, manufacturer, or otherwise does not necessarily constitute or imply its endorsement, recommendation, or favoring by the United States Government or any agency thereof. The views and opinions of authors expressed herein do not necessarily state or reflect those of the United States Government or any agency thereof.

\section{Energy Modeling Forum Stanford University}




\section{PREFACE}

The Energy Modeling Forum (EMF) was established in 1976 at Stanford University to provide a structural framework within which energy experts, analysts, and policymakers could meet to improve their understanding of critical energy problems. The eleventh EMF study, "International Oil Supplies and Demands", was conducted by a working group comprised of leading international oil analysts and decisionmakers from government, private companies, universities, and research and consulting organizations. The EMF 11 working group met four times in 1989 and 1990 to discuss key issues and analyze international oil markets.

This report summarizes the results of the working group study. It is based upon the full working group report and other technical papers prepared during the study. Inquiries about the availability of these other reports should be directed to the Energy Modeling Forum, 406 Terman Center, Stanford University, Stanford, CA 94305 (telephone: 415-723-0645).

Funding for this study was generously provided by the U.S. Department of Energy and member organization of the EMF Affiliates Program. Within the Department of Energy, the EMF received support from the following offices: the Energy Information Administration, the Office of Policy, Planning and Analysis, the Office of Planning and Environment and the Office of Petroleum Reserves within the Office of the Assistant Secretary for Fossil Energy, and the Office of the Assistant Secretary for Conservation and Renewable Energy. Affiliate organizations include: Alberta Department of Energy, ARCO, Central Research Institute of Electric Power Industry (Japan), Conoco, Gas Research Institute, Interstate Natural Gas Association of America, Maxus, Mitsubishi International, National Energy Board (Canada), Pacific Gas and Electric, Shell Oil, Southern California Edison, and Union Pacific Resources. Additional support for this study from Amoco, California Energy Commission, General Motors, Pennsylvania Power \& Light, Benjamin Schlesinger and Associates, and Tenneco is also gratefully acknowledged.

EMF's Senior Advisory Panel continues to offer valuable advice on topics as well as comments and suggestions for improving EMF reports. We would also like to acknowledge Kenneth Ellis, Edith Leni, Pamela McCroskey, Dorothy Sheffield, and Susan Sweency for their assistance in the production of this report.

This volume reports the findings of the EMF working group. It does not necessarily represent the views of Stanford University, members of the Senior Advisory Panel, or any organizations providing financial support. 


\section{CONTENTS}

Preface $\ldots \ldots \ldots \ldots \ldots \ldots \ldots \ldots \ldots \ldots \ldots \ldots \ldots \ldots \ldots \ldots \ldots \ldots \ldots$

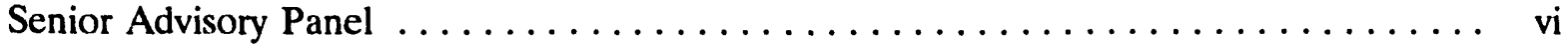

Working Group Participants $\ldots \ldots \ldots \ldots \ldots \ldots \ldots \ldots \ldots \ldots \ldots \ldots \ldots \ldots \ldots \ldots \ldots$

Report Contributors $\ldots \ldots \ldots \ldots \ldots \ldots \ldots \ldots \ldots \ldots \ldots \ldots \ldots \ldots \ldots \ldots \ldots \ldots \ldots \ldots$

EXECUTTVE SUMMARY $\ldots \ldots \ldots \ldots \ldots \ldots \ldots \ldots \ldots \ldots \ldots \ldots \ldots \ldots \ldots \ldots$

INTRODUCTION $\ldots \ldots \ldots \ldots \ldots \ldots \ldots \ldots \ldots \ldots \ldots \ldots \ldots \ldots \ldots \ldots \ldots$

Study Background $\ldots \ldots \ldots \ldots \ldots \ldots \ldots \ldots \ldots \ldots \ldots \ldots \ldots \ldots$

Organization of Summary Report $\ldots \ldots \ldots \ldots \ldots \ldots \ldots \ldots \ldots \ldots \ldots$

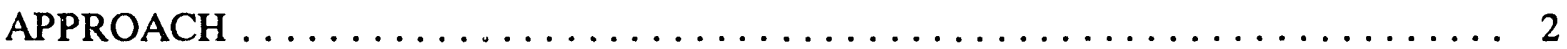

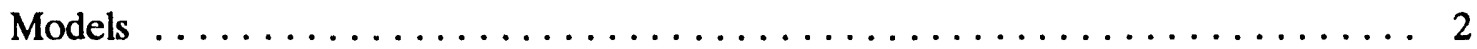

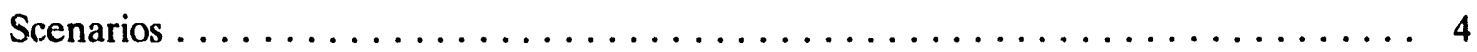

ALTERNATIVE PERSPECTIVES ON SUPPLY AND DEMAND TRENDS $\ldots \ldots \ldots$

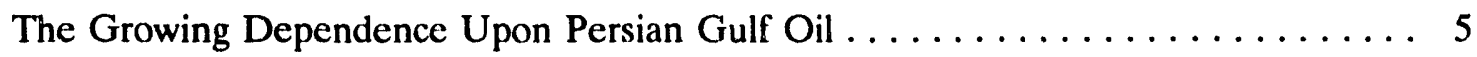

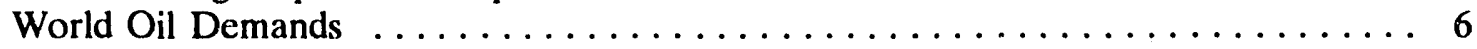

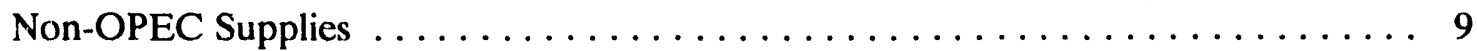

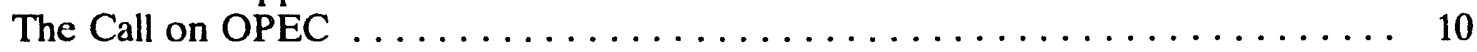

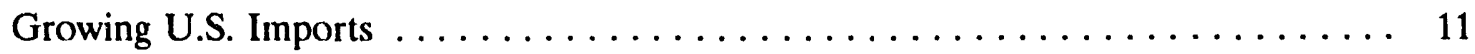

ALTERNATIVE PRICE PATHS $\ldots \ldots \ldots \ldots \ldots \ldots \ldots \ldots \ldots \ldots \ldots \ldots \ldots \ldots$

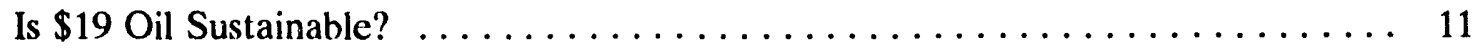

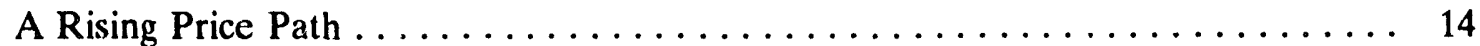

Reducing Dependence Upon OPEC $\ldots \ldots \ldots \ldots \ldots \ldots \ldots \ldots \ldots \ldots \ldots \ldots$

MARKET-CLEARING OIL PRICES $\ldots \ldots \ldots \ldots \ldots \ldots \ldots \ldots \ldots \ldots \ldots \ldots$

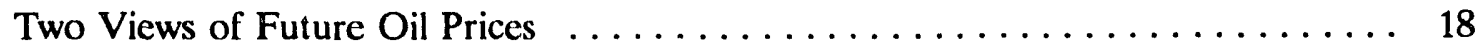

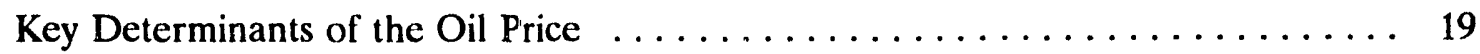

FUTURE DEMAND GROWTH $\ldots \ldots \ldots \ldots \ldots \ldots \ldots \ldots \ldots \ldots \ldots \ldots \ldots \ldots$

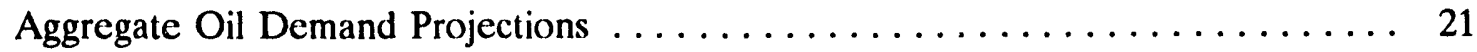

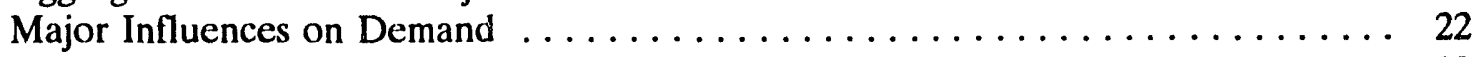

Decomposition of Demand Growth $\ldots \ldots \ldots \ldots \ldots \ldots \ldots \ldots \ldots \ldots \ldots \ldots \ldots$

FUTURE CHALLENGES FOR WORLD OIL MODELING $\ldots \ldots \ldots \ldots \ldots \ldots$

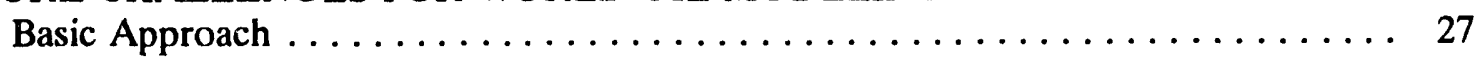

Recommendations for Future Research $\ldots \ldots \ldots \ldots \ldots \ldots \ldots \ldots \ldots \ldots \ldots$

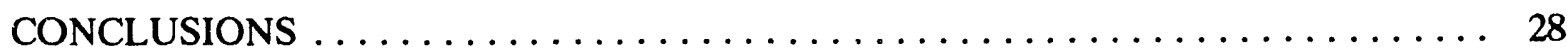

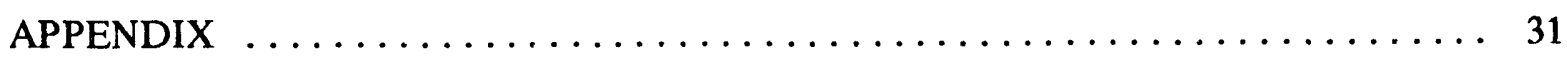

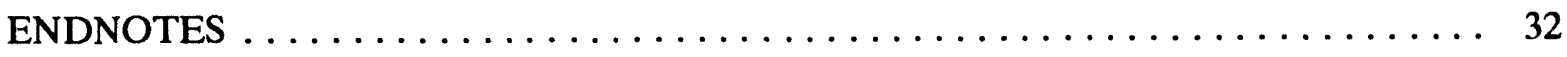

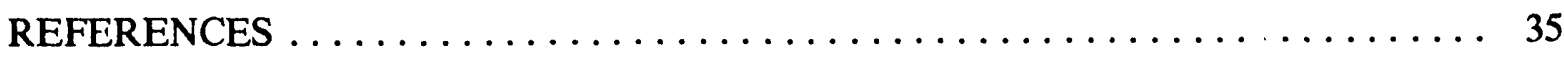




\section{LIST OF TABLES}

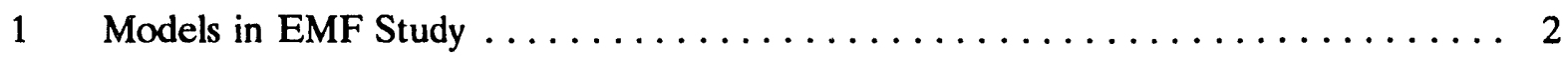

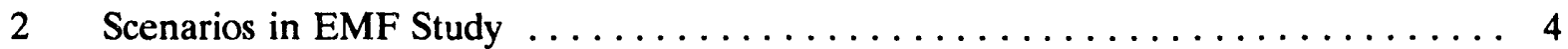

\section{LIST OF FIGURES}

1 World Crude Oil Reserves $\ldots \ldots \ldots \ldots \ldots \ldots \ldots \ldots \ldots \ldots \ldots \ldots \ldots \ldots$

$2 \quad$ Median Results for 1989 IEO Price Path $\ldots \ldots \ldots \ldots \ldots \ldots \ldots \ldots$

3 Market Economies Consumption in 2000 With 1989 IEO Price Path . . . . . . 8

4 Non-OPEC Production in 2000 with 1989 IEO Price Path $\ldots \ldots \ldots \ldots \ldots$

5 Market Economies Supply Sources in 2000 With 1989 IEO Price Path . . . . . . 11

$6 \quad$ U.S. Imports in 2000 with 1989 IEO Price Path $\ldots \ldots \ldots \ldots \ldots \ldots \ldots \ldots$

$7 \quad$ Production Under Flat Price Case With Base GDP Path $\ldots \ldots \ldots \ldots \ldots \ldots \ldots$

8 Production Under Rising Price Case With Base GDP Path $\ldots \ldots \ldots \ldots \ldots$

9 Median U.S. Oil Demand, Supply, and Imports $\ldots \ldots \ldots \ldots \ldots \ldots \ldots$

10 Market-Clearing Price With Cartel $\ldots \ldots \ldots \ldots \ldots \ldots \ldots \ldots \ldots \ldots \ldots$

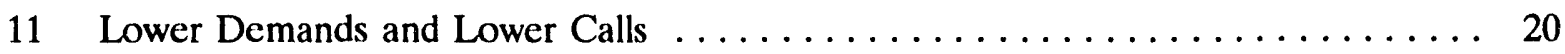

12 OECD Oil-GDP Ratio in Flat Price for Two Different Demands Trends . . . . . 23

13 OECD Demand Growth, 1988-2000: Decomposed into 4 Effects . . . . . . . 25 


\section{Senior Advisory Panel}

The Energy Modeling Forum (EMF) seeks to improve the usefulness of energy models by conducting tests of models in the study of key energy issues. The success of the Forum depends upon the selection of important study topics, the broad involvement of policymakers, and the persistent attention to the goal of improved communication. The EMF is assisted in these matters by a Senior Advisory Panel that recommends topics for investigations, critiques the studies, guides the operations of the project, and helps communicate the results of the energy policymaking community. The panel is not responsible for the results of the individual EMF working group studies.

Professor Morris Adelman

Dr. Richard Balzhiser

The Honorable Danny J. Boggs

The Honorable William Bradley

Mr. Vikram Budhraja

Mr. Stephen D. Chesebro'

Mr. Charles DiBona

Dr. Daniel Dreyfus

Dr. John H. Gibbons

Mr. F. Joseph Graham

Professor William W. Hogan

Mr. Myron F. Kanik

Mr. William F. Martin

Dr. Richard D. Morgenstern

Dr. Roger F. Naill

Ms. Jackalyne Pfannenstiel

Mr. Steven J. Shapiro

The Honorable Philip Sharp

Ms. Linda Stuntz

Professor James L. Swceney
Massachusetts Institute of Technology Electric Power Research Institute U.S. Sixth Circuit Court The U.S. Senate Southern California Edison Company Tenneco Gas American Petroleum Institute Gas Research Institute Office of Technology Assessment Union Carbide Harvard University Alberta Department of Energy Miller \& Chevalier

U.S. Environmental Protection Agency Applied Energy Services Pacific Gas \& Electric Company ARC.O

U.S. House of Representatives U.S. Department of Energy Stanford University 
Working Group Participants

Chairman: W. David Montgomery, Charles River Associates†

Arthur Andersen

Nicholas Baldwin

Michael Barron

Robert Bidwell

Jay Braitsch

Guy Bridgeman

Stephen P.A. Brown

Nazli Choucri

Larry Edwards

Edward Flom

Dermot Gately

William W. Hogan

Hillard G. Huntington

Mudassar Imran

Robert Kaufmann

David H. Knapp

Paul Leiby

Alan S. Manne

Gene Meyer

Dale Nesbitt

David Nissen

Edward Porter

Anthony Reinsch

Mark Rodekohr

Kjell Roland

David Root

Jayant Sathaye

John Sauer

Mark Segal

James L. Sweeney

Paul Tossetti

Thanos Trezos

Philip K. Verleger

E. Lakis Vouyoukas

John P. Weyant

\author{
U.S. Department of Energy \\ PowerGen, U.K. \\ Maxus \\ U.S. Department of Energy \\ U.S. Department of Energy \\ Alberta Department of Energy \\ Federal Reserve Bank of Dallas \\ Massachusetts Institute of Technology \\ Tenneco Gas \\ Amoco \\ New York University \\ Harvard University \\ Stanford University \\ World Bank \\ Boston University \\ Brown Bros. Harriman \& Co. \\ Oak Ridge National Laboratory \\ Stanford University \\ Shell Oil Company \\ Decision Focus, Inc. \\ Poten \& Partners, Inc. \\ American Petroleum Institute \\ Canadian Energy Research Institute \\ U.S. Department of Energy \\ ECON, Center for Economic Analysis, Norway \\ U.S. Geological Survey \\ Lawrence Berkeley Laboratory \\ Conoco, Inc. \\ National Energy Board \\ Stanford University \\ ARCO \\ Southern California Edison Company \\ Institute for International Economics \\ International Energy Agency* \\ Stanford University
}

†Affiliation at time of study: U.S. Congressional Budget Office

*Affiliation at time of study: BP America 


\section{Report Contributors}

Several people supported the working group in developing background material and attending one or more meetings. We would like to particularly acknowledge the significant contribution of the following people:

\author{
J. Allen Coombs \\ Maureen Crandall \\ Carol A. Dahl \\ David DeAngelo \\ Kenneth Ellis \\ Dennis Eoff \\ Konrad Fassbender \\ Lowell Feld \\ Richard Hilt \\ James A. Kimball \\ Eric Kreil \\ Andrea Kress \\ Arild Moe \\ James Page \\ Douglas Robinson
}

Energy Mines \& Resources U.S. Department of Energy Louisiana State University Pennsylvania Power \& Light Stanford University California Energy Commission Alberta Department of Energy

U.S. Department of Energy Gas Research Institute Pacific Gas \& Electric U.S. Department of Energy Stanford University Fridtjof Nansen Institute, Norway California Energy Commission Stanford University 


\section{EXECUTIVE SUMMARY}

Since the mid-1980s the world economy has increased its dependence on oil supplies from the Persian Gulf. The oil price response to the Iraqi invasion of Kuwait in August 1990, and the ensuing war between Iraq and allied forces underscore the world's vulnerability to future oil price shocks, given the long-run trend towards increased dependence upon oil from this region.

The eleventh Energy Modeling Forum (EMF) working group met four times over the $1989-90$ period to compare alternative perspectives on international oil supplies and demands through 2010 and to discuss how alternative supply and dernand trends influence the world's dependence upon Middle Eastern oil. Proprietors of eleven economic models of the world oil market used their respective models to simulate a dozen scenarios using standardized assumptions. From its inception, the study was not designed to focus on the short-run impacts of disruptions on oil markets. Nor did the working group attempt to provide a forecast or just a single view of the likely future path for oil prices. The model results guided the group's thinking about many important longer-run market relationships and helped to identify differences of opinion about future oil supplies, demands, and dependence.

\section{Dependence Upon Middle Eastern Oil}

The results from a number of different models and scenarios led to several key conclusions about the world's dependence upon Middle Eastern oil:

- Dependence upon Middle Eastern oil will grow in the future, despite widely different views on the future levels of prices, supplies, and demands. This growing dependence will increase the exposure of the world economy to the substantial insecurity of oil supplies that has been so characteristic of this region.
- The share of oil imports will rise quickly in many major energy-consuming countries. Even with steadily higher oil prices, about two of three barrels consumed within the United States are likely to be imported by 2010 .

- While oil production and consumption in the Non-OPEC countries are moderately. sensitive to oil prices, this growing dependence upon Middle Eastern oil supplies probably cannot be halted or reversed even if oil prices within the oil-consuming nations were to be greatly increased through taxation or other incentives. For this reason, policies for limiting oil imports are likely to be insufficient for eliminating or containing this dependency. Policy measures may also need to include oil stockpiles, monetary and federal tax policies for stabilizing the economy, and other measures to help the economy adapt to future price shocks caused by instability in oil supplies.

\section{Oil Demands and Supplies}

These conclusions about dependency are robust across a range of alternative demand and supply projections. Major conclusions about differences in demand and supply trends include:

- After many years of changing energy prices, fluctuating economic growth and stifting government policy, there is little agreement about how these factors will affect the rate of increase in future demand. While projected oil demand in the market economies is virtually stagnant or growing very modestly by 2000 in some models, it grows briskly in others. Although the wide range in projections is disconcerting, the existence of fundamentally different views can be expected. Analysts assign different values to demand responses to price, economic growth, and technical change. They must draw these values from a limited histor- 
ical experience containing several sharp shifts in trends for price, economic growth, and oil quantities.

- Projections at the higher end of the spectrum hold that oil demand will grow proportionally with economic growth if oil prices remain unchanged. In addition, they indicate rising oil intensity over the next five years because recent prices (after adjusting for inflation and excluding the price spike during the Iraqi invasion of Kuwait) have been below previous prices during the 1970s and early 1980s. Since oil demand adjusts only gradually to price changes, the price declines during the late 1980 s will continue to stimulate oil deman' growth during the 1990 s.

- Conversely, demart projections at the lower end show continued improvements in oil efficiency even without higher oil prices. They also project little additional stimulus to future demand resulting from the price declines of the $1980 \mathrm{~s}$.

- After many years of changing oil prices, fiscal policies of oil-producing countries, and regulatory regimes, there is little agreement about how these factors will influence the level of future oil supply. There is agreement that U.S. supplies will fall regardless of price assumptions because new reserves will be increasingly more expensive. Outside the United States, resource costs appear to be less important than institutional constraints such as infrastructure, taxation, and government ownership of oil-producing enterprises. Projected supplies in these less mature regions either grow or remain relatively stable. Given data constraints and the immense political and economic uncertainty in the USSR, the study has not addressed the potential for net Soviet oil exports. While the bleak economic and political outlook portend declining oil exports over the next few years, a favorable resolution of these conditions could make the USSR an important source of additional world oil supplies in the longer term.

- When oil prices are held constant at $\$ 19$ (all prices are in 1990 U.S. dollars) over the $1989-2010$ period, the projected supply and demand levels in all models reveal strong pressures for OPEC members to either expand production rapidly or increase prices. The median result calls for OPEC to expand production by $5.2 \%$ per annum between 1990 and 2000 to meet the oil demand generated by world economic growth of about $2.9 \%$ per annum. Many oil analysts think that OPEC would not increase production so quickly, requiring higher prices to reduce world demand and increase production outside OPEC. Over the next decade, a combination of factors could reduce the call on OPEC, and hence the pressure for higher prices, below the range estimated here. It becomes much more difficult to sustain this price path through the next two decades, requiring either significantly less cooperation among OPEC members or very early development of inexpensive unconventional oil supplics at prices substantially below those considered likely today.

\section{Oil Prices}

In addition, while the study placed much iess emphasis on projecting what the future oil price would be, the group emphasized two conclusions about market-clearing oil prices:

- Projected market-clearing oil prices, determined by the interaction of supply and demand conditions, rise over time in all models, although at substantially different rates. Two distinct sets of price paths are evident. Low demand growth and expanding OPEC output keep prices in several models along a low-growth track, increasing to the low $\$ 20$ s by 2000 and to about $\$ 30$ by 2010 . Substantially higher oil prices result when either demand growth is more rapid or OPEC output is constrained to $37 \mathrm{MMBD}$ 
or less. The latter limit reflects a combination of economic and political conditions including: declining net income (discounted) at higher production levels, limited ability to absorb additional oil revenues, and a reluctance to sell more of a "patrimonial resource".

- In combination with the previous discussion of the flat price scenarios, these results suggest that oil prices are unlikely to remain consistently below $\$ 20$ per barrel over the next two decades. At the higher end, it is unlikely that the long-run sustained oil price path over the next decade will exceed the 1981 peak of $\$ 55$ (in 1990\$) during the secon! oil price shock. Within this wide range, uncertainty about external factors like world economic growth, oil supply and demand responses to prices and economic growth, and political developments in oil-producing and oil-consuming countries can lead to a number of plausible outcomes.

\section{Further Work Needed}

In the study, existing models of the world oil market were used to quantify certain key relationships important for understanding this market and to highlight major areas of agreement as well as differences. By providing a consistent framework for evaluating a number of important factors, the models have been very useful for advancing the group's discussion and for revealing the implications of various oil supply and de mand trends for future oil prices and dependence upon OPEC supplies. However, even after many years of energy policy debates, several research and modeling issues remain open. The working group identified four critical areas where a revival of research and modeling would be particularly usieful for improving the state of analysis of world oil markets:

- The most critical challenge to future modeling appears to be ways to represent the cartel's long-run output decision. Decisions about when and by how much the cartel will expand capacity need to be linked to the market conditions being determined elsewhere in the model. Extensions to incorporate the possibility of rivalry within OPEC and its impact on long-run capacity decisions should also be encouraged.

- Another critical concern is to resolve the disparate views on future trends in oil use efficiency. Additional study is needed to separate the effects of current prices from past prices and other nonprice factors such as technological progress or shifts in the economy's composition of goods and services. Furthermore, while oil demand growth is expected to be concentrated in the developing countries, poor data often prevent careful analyses of their energy production, use, and balance-of-payment constraints.

- Many existing models focus on oil only, giving limited attention to interfuel substitution issues. Environmental policies and more abundant natural gas supplies can alter substitution opportunities, perhaps dramatically changing the oil market picture. Some expanded capability to handle these issues will become increasingly important.

- Analyses of world oil market conditions are severely limited by the unavailability of reliable data on the cost of producing oil in major supply regions outside the United States. Moreover, the role of technology and the effect of producing-country tax policies in enhancing future oil supplies are poorly understood. 


\section{INTRODUCTION}

Since the mid-1980s the world economy has increased its dependence on oil supplies from the Persian Gulf. After several years of stagnating world economic growth and oil demand, oil use rose sharply beginning with the oil market collapse in 1986. At the same time, oil production outside the Middle East stabilized after expanding significantly during the first half of the decade.

The oil price response to Iraqi invasion of Kuwait in August 1990, and the ensuing war between Iraq and allied forces, demonstrate: the inherent instability of an oil market sc dependent upon relatively inexpensive supplies from the Persian Gulf. Even though most of the 4.3 million barrels per day (MMBD) of lost Iraqi and Kuwaiti production was replaced with surge production from other countries, prices rose sharply in the weeks after the August invasion, with spot prices reaching $\$ 40$ per barrel in October when fears of expanded military conflict intensified. This crisis underscores the world's vulnerability to future oil price shocks, given the long-run trend towards increased dependence upon oil from this region.

\section{Study Background}

This report summarizes the key results of the eleventh Energy Modeling Forum (EMF) study, henceforth referred to as EMF 11 , focusing on international oil supplies and demands through 2010. In May 1989, the EMF commenced this study to compare alternative perspectives on supply and demand issues and to discuss how alternative supply and demand trends influence the world's dependence upon Middle Eastern oil. How rapidly will world oil demand grow? Will supplies outside OPEC increase, stabilize, or decline? What are the long-run implications of these demand and supply trends for the world's dependence on oil from OPEC member countries and particu- larly from the Persian Gulf? And do these trends make us more or less concerned about possible future oil disruptions?

From its inception, the study was not designed to focus on the short-run impacts of disruptions on oil markets. Other analytical frameworks would have been chosen had short-run oil market dynamics been the primary intcrest.

Nor did the working group attempt to provide just a single view of the likely future path for oil prices. For one thing, the key conclusions about the growing dependence upon Middle Eastern oil do not depend upon the oil price outlook. Moreover, three oil shocks and two major price collapses within two decades show the perils of oil price forecasting. There exists considerable uncertainty about the basic economic forces influencing the oil demand and supply conditions that determine oil prices. Moreover, the market outcome is critically dependent upon how these economic forces interact with a set of highly unpredictable political factors. While these problems limit the usefulness of precise price forecasts, they increase the value of probing the range of possible market outcomes in order to understand how basic economic forces lead to alternative oii market conditions.

\section{Organization of Summary Report}

After a brief description of the general approach, the models, and the scenarios, the report summarizes the main conclusions. In analyzing the results, the report begins with a comparison of the projected supply and demand trends when all models use a common oil price path. Then, the response of supply and demand to alternative oil price paths is considered. Finally, these findings are integrated to explain the factors determining differences in the market clearing oil price projected by the models. 
Table 1. Models in EMF Study

\begin{tabular}{ll} 
Model & Working Group Contact* \\
\cline { 2 - 2 } EIA:OMS & Mark Rodekohr, Energy Information Administration \\
IPE & Nazli Choucri, Massachusetts Institute of 'Technology \\
ETA-MACRO & Alan Manne, Stanford \\
WOMS & Nicholas Baldwin, PowerGen, U.K. \\
CERI & Anthony Reinsch, Canadian Energy Research Institute \\
HOMS & William Hogan, Harvard, and Paul Leiby, Oak Ridge National Laboratory \\
FRB-Dallas & Stephen P.A. Brown, Federal Reserve Bank of Dallas \\
DFI-CEC & Dale Nesbitt, Decision Focus, Inc. \\
BP America & E. Lakis Vouyoukas, British Petroleum \\
Gately & Dermot Gately, New York University \\
Penn-BU & Peter Pauly, University of Pennsylvania and University of Toronto, and \\
& Robert Kaufmann, Boston University
\end{tabular}

*Organization listed for identification purposes. Models and results do not necessarily represent afficial view of listed organization.

\section{APPROACH}

As in previous EMF studies, the research was conducted by an ad hoc working group of more than 40 leading analysts and decisionmakers from government, industry, academia, and other research organizations. In the EMF process, the working group pursues the twin goals of (1) improving the understanding of the capabilities and limitations of existing energy models and (2) using these models to develop and communicate useful information for energy planning and policy. A key objective is to foster an improved dialogue between the developers and potential users of world oil models.

The EMF 11 working group met four times over the $1989-90$ period to develop a study plan with a set of carefully selected scenarios, analyze model results and supporting research, and develop key conclusions and insights. Proprietors of 11 economic models of the world oil market used their respective

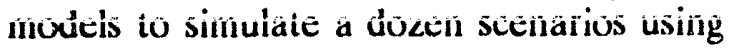

standardized assumptions. The model results guided the larger group's thinking about many important market relationships and helped to identify differences of opinion about future outcomes.

\section{Models}

The 11 world oil models used in this study are listed in Talle 1 with the name of the working group representative and affiliated organization. Since the modelers used EMF standardized assumptions for prices, economic growth, and cartel capacity, these projections are not forecasts of the particular organizations. Moreover, the institutional affiliation listed in Table 1 is given to identify the model rather than to indicate an official modeling framework of a particular organization. ' This caveat applies particularly to BP America, WOMS, and the Federal Reserve Bank of Dallas, as well as the vãiouous university mơdels. 


\section{OIL MARKETS AFTER THE PERSIAN GULF CRISIS}

The scenarios in this study were specified and finalized prior to Iraq's invasion of Kuwait and the ensuing Persian Gulf war. The working group met for a fourth and final time, one month after the initial invasion, to review the major conclusions of the analysis. During this meeting, the group extensively discussed the usefulness and limitations of these models and projections, in light of the Persian Gulf crisis.

The invasion underscored the difficulty of anticipating when political events will disrupt oil markets. Once the disruption occurred, moreover, oil prices were influenced by such shortrun factors as inventory building in anticipation of how hostilities would be resolved. The world oil models used in this study focus upon the longer-run economic conditions influencing oil supply and demand and are therefore not appropriate for studying the timing of disruptions and their near-term effect on oil prices.

At the same time, models such as those uscd in this study were useful for establishing that the spiraling oil prices in response to the crisis were well above levels that were consistent with long-run economic conditions in 1990. The combination of slack oil market conditions with substantial oil replacement potential from other countries indicated that oil prices would soon return to their lower levels. While oil prices surpassed $\$ 40$ per barrel on some days during 1990, the average oil price for the year was about $\$ 23$ per barrel, a level only slightly higher than the average projected 1990 level in the market-clearing scenario in this study. The group was confident that prices would return to their lower levels after the uncertainty about war outcomes was resolved, and they did.

The Persian Gulf crisis of 1990 is also likely to have some long-lasting impacts on the oil market. Will increased western military presence in the Persian Gulf enhance the security of oil investments in the region? Has the crisis strengthened the political position of the monarchial states, who have traditionally sought lower prices, or ultimately the more populist regimes, who have tended to adopt more aggressive pricing policies? While the models will not help to resolve the uncertainty in these geopolitical issues, they provide an essential framework for understanding the economic implications of different Middle Eastern policy regimes on the world oil markets. Any effort to reconsider oil markets after the invasion of Kuwait must include a thorough analysis of the same supply and demand issues discussed in this study.

The models were developed to prepare long-run projections of oil prices, oil production, and oil consumption and to study changes in these variables under alternative scenarios. They incorporate the behavior of three distinct types of decisionmakers: oil consumers, oil producers outside the cartel, and oil producers within the cartel. Most models report prices and supply-demand balances annually and focus exclusively on world oil markets.? Alternative fuel price and interfuel substitution are not explicitly represented. Instead, competing fuel prices in the future are assumed to change with oil prices as they have in the past. The response of oil demand to changes in these other fuel prices is also based upon historical expericnec.
In these models, oil consumers respond to Gross Domestic Product (GDP), energysaving trends in technology or economic structure (if present), and oil prices. Shifts in the economies' structures are seldom incorporated explicitly, because each region's economy is represented as one aggregate sector. The response of oil producers outside the cartel is governed by assumptions about trends in resource depletion and technology in addition to oil prices. By basing parameter values on historical experience, most models assume that past regulatory policies will be continued into the future. Some models may adjust these responses to reflect expected changes in regulation and fuel substitution. 
Table 2. Scenarios in EMF Study

Predetermined Price Path Scenarios:

1. Flat Oil Price (with Base GDP Path)

2. Rising Oil Price (with Base GDP Path)

3. 1989 IEO Price

4. Flat Oil Price with High GDP Path

5. Flat Oil Price with Low GDP Path

6. Rising Oil Price with High GDP Path

7. Rising Oil Price with Low GDP Path

8. No Economic Growth (with Flat Oil Price)

9. No Economic Growth or Technological Time Trend (with Flat Oil Price)

Market-Clearing Price Scenarios:

10. Cartel Case (with Base GDP Path)

11. Cartel Case (with High GDP Path)

12. Competitive Case (with Base GDP Path)

In most models, the cartel's productive capacity is predetermined, based upon modeler judgment of a combination of economic and political constraints. The cartel sets a price based upon last period's price and rate of utilization of its capacity based upon a relationship that explains price movements somewhat better in the 1970 s than in the 1980s. In this way, oil prices, production, and consumption are determined recursively; market conditions in one year influence those in the succeeding year.

\section{Scenarios}

The working group considered a dozen scenarios, listed in Table 2 , in which all modelers used the same input assumptions for economic growth and OPEC capacity. The first nine scenarios also specified a predetermined price path that was to be assumed by each modeler. Specific model assumptions about OPEC's behavior or resporises to market conditions were not used in these scenarios. Instead, the oil- producing cartel is considered to be a passive participant, operating as a residual supplier of oil, meeting all oil demand that remains unsatisfied by non-OPEC production. Price and economic growth assumptions are discussed together with the major findings.

These first nine scenarios were developed to allow a standardized comparison of the projected supply and demand trends in various models across a wide range of reasonable oil price and GDP paths. They also help to interpret the results from three additional scenarios where supply and demand conditions, including OPEC production decisions, are allowed to determine a market-clearing oil price in each model. ${ }^{3}$

It should be emphasized that modelers were requested not to impose any shifts in government policies in running these cases. Many working group members thought that oilimporting countries would impose taxes and other conservation policies to limit their oil demands. Thus, the EMF scenarios should 
Figure 1. World Crude Oil Reserves

January 1, 1990 (Billion Barrels)

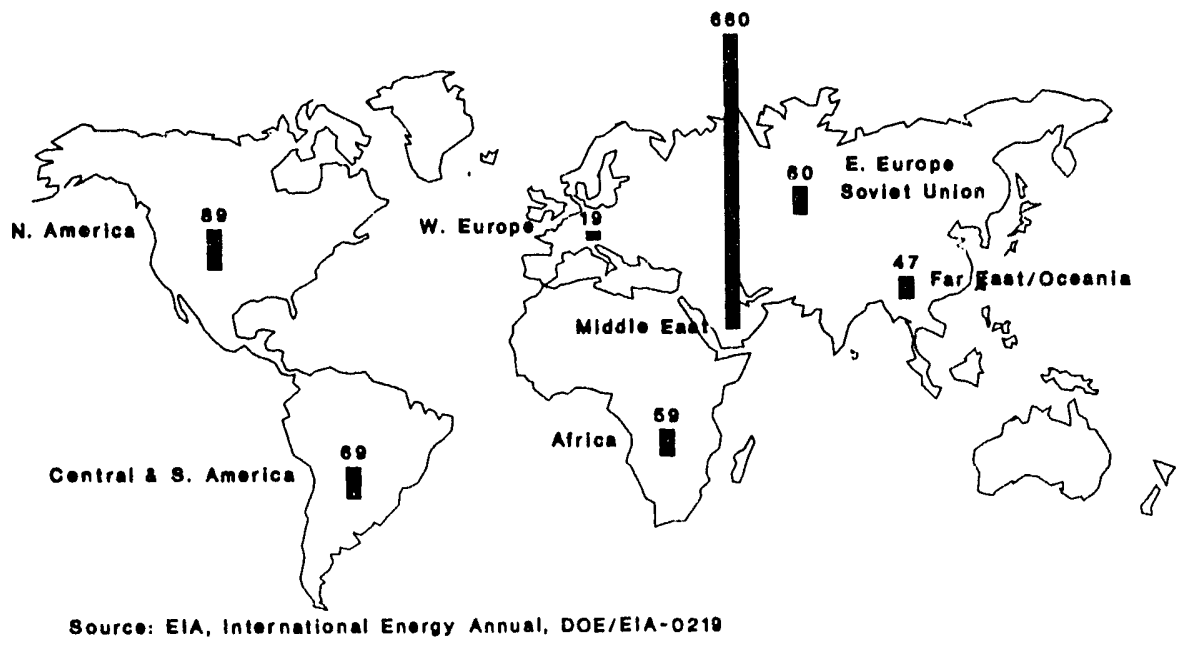

be considered as revealing the pressures that would emerge under alternative oil price and GDP paths if no such policies were implemented.

The price trajectories in this study should be viewed as paths averaging over several decades. Almost surely, actual year-to-year prices will deviate from the long-run paths reflecting short-term shifts in market conditions. In addition, the study has not tried to anticipate future shifts in foreign exchange rates that could affect the price of oil in local currencies and ultimately the dollardenominated price.

\section{ALTERNATIVE PERSPECTIVES ON SUPPLY AND DEMAND TRENDS}

\section{The Growing Dependence Upon Persian Gulf Oil}

Dependence upon Middle Eastern oil will grow in the future, despite wide differences in quantitative estimates of prices, supplies, and demands. Current oil reserves are heavily concentrated in the Middle East (Figure 1); furthermore, this oil is inexpensive to produce relative to oil in other regions. 4

Many of the study's key findings can be summarized by discussing the results from one scenario--the 1989 IEO price case. Unless noted otherwise, the conclusions discussed here apply broadly to the other scenarios as well. This scenario was based upon the mid-price case in the Energy Information Administration's 1989 International Energy Outlook (IEO). After dramatic declines in actual oil prices between 1981 and 1986, this scenario calls for the long-run, sustained oil price path to remain relatively flat in the high teens through the early 1990 s, before rising to $\$ 30$ a barrel by 2000 and to $\$ 39$ a barrel by 2010 . (All prices are in 1990 U.S. dollars.) This path shows the oil price path that can be sustained over the long run; prices in the short run can be either above or below this path. The market 
economies are assumed to grow at $2.9 \%$ per annum over the $1990-2010$ period in this scenario, with higher economic growth $(4.1 \%$ p.a.) outside the OECD countries. Finally, any additionai policies to reduce oil demand in the major economies are not incorporated. While one might expect some demand reduction policies in the United States, other countries already have made considerable progress in shifting away from oil.

The median results ${ }^{5}$ represented in Figure 2 highlight the growing dependence upon OPEC and the Persian Gulf found in all models. After leveling out during the 1980s, oil consumption in the market economies begins to rise, with much of this growth occurring within the developing countries (particularly, in the Pacific Rim). Oil production outside OPEC member countries falls gradually through 2000 and more steeply during the initial decade of the next century. While production within the United States falls, production in other regions remains relatively stable in many models. The median result shows a very modest decline in non-OPEC production--a noticeable break in the upward trend observed for the 1980s. Despite the higher prices in later years, production declines because geologic depletion in mature areas offsets exploratory finds in new regions, technological progress, and improved economic incentives. As a result of gradually rising demand and falling or stable production outside the cartel, dependence upon OPEC and Persian Gulf sources grows throughout the next two decades. Increasing demand in a market with OPEC output growing only moderately, across a range of conditions, is the major explanation for gradually increasing oil prices over the longer run, such as with the 1989 IEO price path. If OPEC members in this scenario were to act simply as residual suppliers--producing whatever quantities to meet the excess demand not being supplied by non-OPEC production--their production (median result) would grow from 21.5 MMBD in 1988 to 36.7 MMBD by 2000 and to 43.2 MiMíD by 2010 . Míoreover, the strong upward trend in OPEC production is robust across the models.

Rapidly growing OPEC production means that world oil production will increasingly be concentrated in the lower-cost regions, principally the Persian Gulf producers within OPEC. The percent of oil supplies for the market economies originating from OPEC countries (bottom of Figure 2) rises from $43 \%$ in 1988 to $58 \%$ by 2000 . The Persian Gulf's market share also rises substantially from $27 \%$ in 1988 to $42 \%$ by 2000 .

Growing dependence upon Persian Gulf oil will have major energy security implications, even for countries that import little or no oil. As the world's dependence upon this source increases, interruptions in the flow of oil from that region will cause larger oil price shocks. Past price shocks severely depressed economic activity in both energyexporting and energy-importing countries. ${ }^{7}$ A particular country's dependence upon oil imports does not necessarily change this outlook and is therefore less important from an energy security perspective.

These trends are based upon the assumption that OPEC members would become residual suppliers at the prices assumed in the 1989 IEO price path. In fact, OPEC could adopt several different strategies that would influence the oil price in significant ways. While there remains considerable uncertainty about OPEC's behavior, the EMF 11 results suggest strongly that OPEC's increasing market share will materialize, even in scenarios where it influences prices through cooperative behavior.

\section{World Oil Demands}

After many years of changing energy prices, fluctuating economic growth, and shifting government policy, there remains considerable uncertainty about how these factors will influence future oil demand. While oil demand in the market economies is virtually stagnant or growing very modestiy by 2000 in 
Figure 2. Median Results for 1989 IEO Price Path
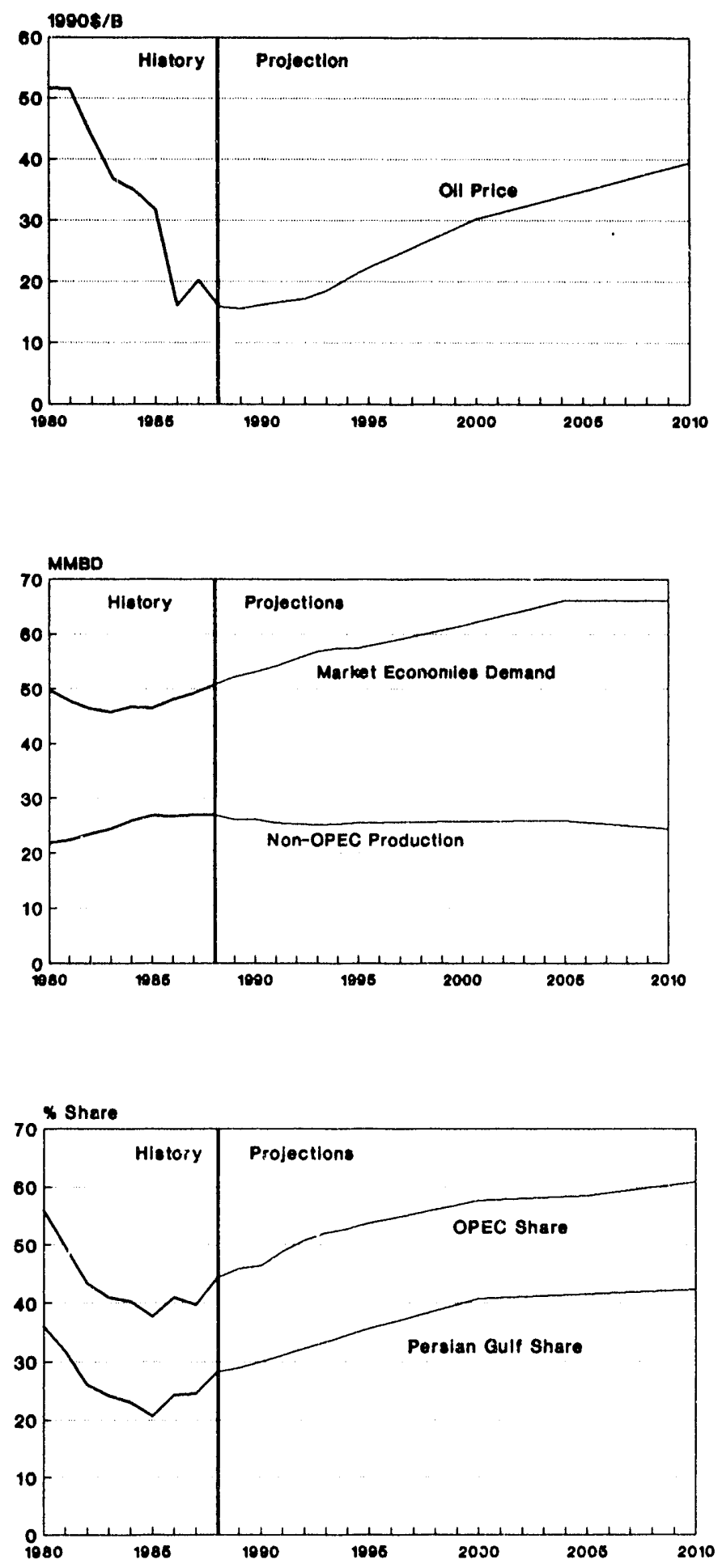


\section{Figure 3. Market Economies Consumption in 2000 with 1989 IEO Price Path}

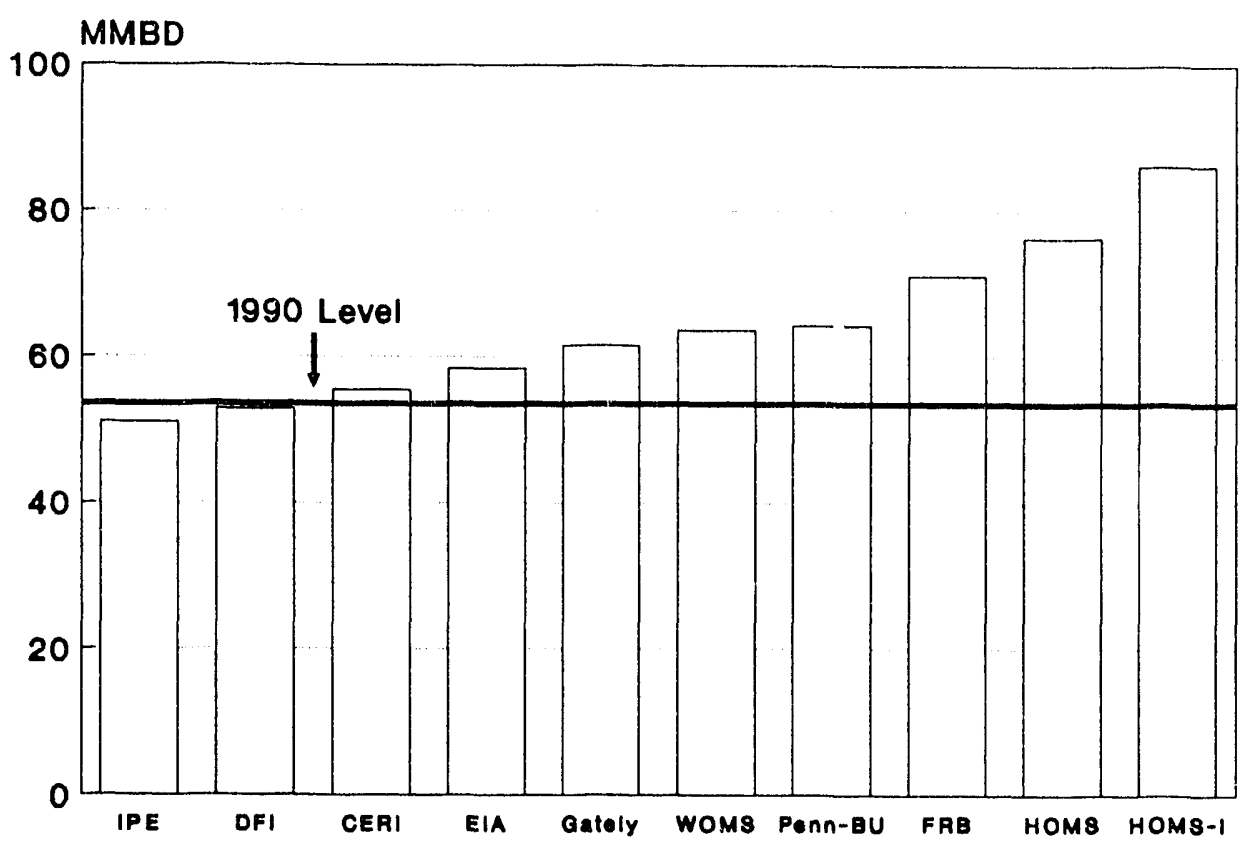

some models (e.g., IPE and DFI shown at the left in Figure 3), it grows briskly in others (HOMS nd FRB-Dallas, shown at the right in the surce fiure). By 2000 , there exists a 30 MMBD difference in demand projections (Figure 3), despite the common oil price and economic growth assumptions.

While the wide range in projections is disconcerting, the existence of fundamentally different views can be expected. Oil demand projections incorporate the separate effects of several key factors: the current oil price, economic growth, technical change influencing oil demand independently of price, and past oil prices (since demand adjusts slowly to price). Analysts determine different values for the demand response to these factors, based upon a limited historical experience containing several sharp shifts in trends for price, economic growth, and oil quantities. In the 1950s and 1960s, GDP and oil demand grew at roughly comparable rates. Over the next decade, real oil prices rose sharply, causing oil demand to grow less rapidly than GDP in many countries. During the $1980 \mathrm{~s}$, oil consumption declined or grew very slowly, as other fuels displaced residual fuel oil in powerplants and major stationary industrial applications. The transportation sector, on the other hand, has remained almost totally dependent on gasoline and jet fuel for airplanes. Since 1986, total oil use has grown more rapidly during a period of widespread economic recovery and lower oil prices.

At the moment, it is uncertain whether the decoupling of oil use and economic growth in past periods will continue, and at what rate. Once residual fuel oil has been displaced in many applications, oil use trends will be heavily dominated by the growing transportation demand for gasoline and jet fuel. Moreover, there may be renewed reliance upon heavy fuel oil for new generating capacity and industrial installations in economies with severe capital constraints. 
Projections at the higher end of the spectrum view that oil demand will be strongly stimulated by economic growth; a $1 \%$ increase in GDP results in a $1 \%$ increase in oil use in both HOMS and FRB-Dallas, if oil prices remain unchanged. Moreover, in the absence of higher prices, there exists no long-run trend towards more efficient energy use in these projections. While some new technologies save energy, other technologies and lifestyle changes use more energy.

Conversely, demand projections at the lower end show continued improvements in oil efficiency even without higher oil prices. Within this group, oil intensities (oil use per dollar of GDP) at the higher end are falling at approximately the same rate as they did in the late 1980s, while those at the lower end decline more rapidly, more in line with the experiences of the late 1970s.

Another surprising source of discrepancy between oil demand projections is the gradual effect of lower oil prices since 1986 on oil demand during the 1990s. Contributing to the higher demand projections of the first group is the belief that oil use will rise more rapidly than economic growth over the next five years because recent prices (after adjusting for inflation and excluding the price spike during the Iraqi invasion of Kuwait) have been below previous prices during the 1970 s and early 1980s. Since oil demand adjusts only gradually to price changes, the price declines during the late 1980 s will continue to stimulate oil demand growth during the $1990 \mathrm{~s}$. In contrast, there is little additional stimulus to future demand resulting from the price declines of the 1980s in the lower demand projections. The significance of this source of demand growth to some projections is demonstrated by the fact that there exists a 16 MMBD difference between projections as early as 1995 .

\section{Non-OPEC Supplies}

After many years of changing oil prices, fiscal policies of oil-producing countries, and regulatory regimes, there is little agreement about how these factors influence the level of future oil supply. Estimates of oil production outside OPEC (excluding the Soviet Union) under these same oil price assumptions are shown in Figure 4, which adopts the same vertical scaling as in Figure 3 as well as ordering of models, i.e., from lowest to highest total demand, moving from left to right. Differences in production are less pronounced than for the market economies demand. Production ranges from 24 to 32 MMBD by 2000 ; by 2010 , the range widens considerably to 20-38 MMBD.

This smaller variation in production estimates does not reflect greater certainty in future oil supply than demand levels. Many models are based upon the same geologic resource base estimates and use similar assumptions about constraints on expanding future supplies, even though considerable uncertainty exists about both the resource base and these drilling constraints. Moreover, relative to the average projected level, the range in production estimates is not noticeably smaller than that in consumption. While projected oil demands grow over the period, projected non-OPEC supplies fall or remain stable for the most part.

Even after a decade of growth in non-OPEC supplies, most analysts anticipate future oil production from these areas to decline over the next decade. Higher resource costs and limits on expanding oil drilling in newer regions lacking a supporting infrastructure contribute to this decline in production. Non-OPEC production is highest in HOMS and FRB-Dallas, neither of which explicitly links its production estimates to resource 
Figure 4. Non-OPEC Production in 2000 with 1989 IEO Price Path

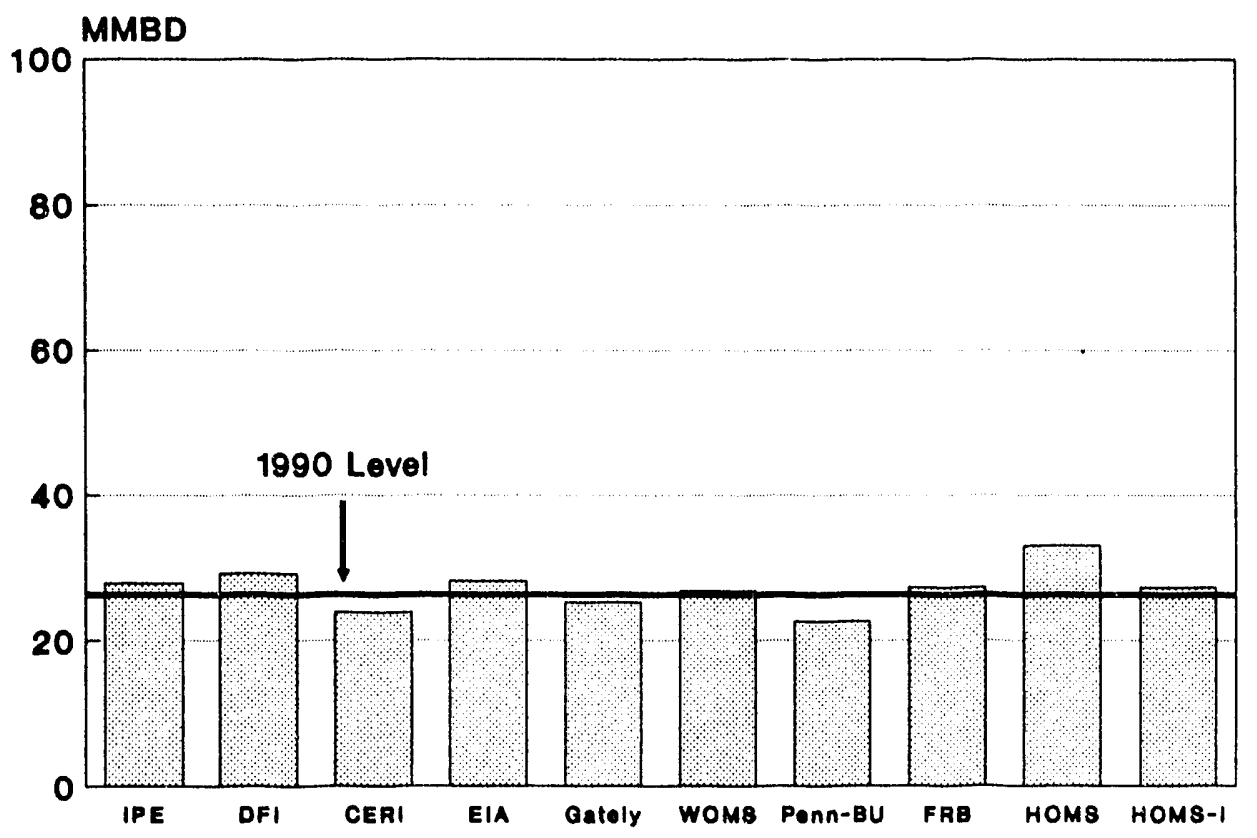

estimates. Instead, production changes over time and with the oil price path, based upon responses that have been derived statistically from historical data.

There is agreement that U.S. supplies will fall regardless of price assumptions because new reserves become increasingly expensive. By contrast, projected supplies in less mature regions outside the United States either grow or remain relatively stable. While oil exploration and discovery in these newer regions generally are less costly than in the United States, institutional constraints such as infrastructure, taxation, and government ownership of oil-producing enterprises often restrict oil-producing activity from expanding rapidly.

In general, analysis of supply decisions is hindered by inadequate information about the costs of various resources, the impetus for technological advancement in oil exploration and production, and the role of gov- ernment intervention through changes in fiscal (tax) policies.

\section{The Call on OPEC}

Despite these substantial differences in supply and demand projections, there exists a consensus on the rising dependence upon OPEC oil during the next two decades. As a result of growing world demand and relatively flat (sometimes declining) non-OPEC production, the demand for OPEC oil increases strongly in virtually all models. ${ }^{8}$ Figure 5 combines the information in Figures 3 and 4 to reveal the widening gap between total demand and non-OPEC production that must be met by OPEC members to keep prices along the 1989 IEO price path. OPEC's production of $21.5 \mathrm{MMBD}$ in 1988 would need to grow to a range of 25-45 MMBD by 2000 , depending upon the model. Currently more than 40 percent of the market economies oil demand originates in OPEC countries. The median share 
Figure 5. Market Economies Supply

Sources in 2000 with 1989 IEO Price Path

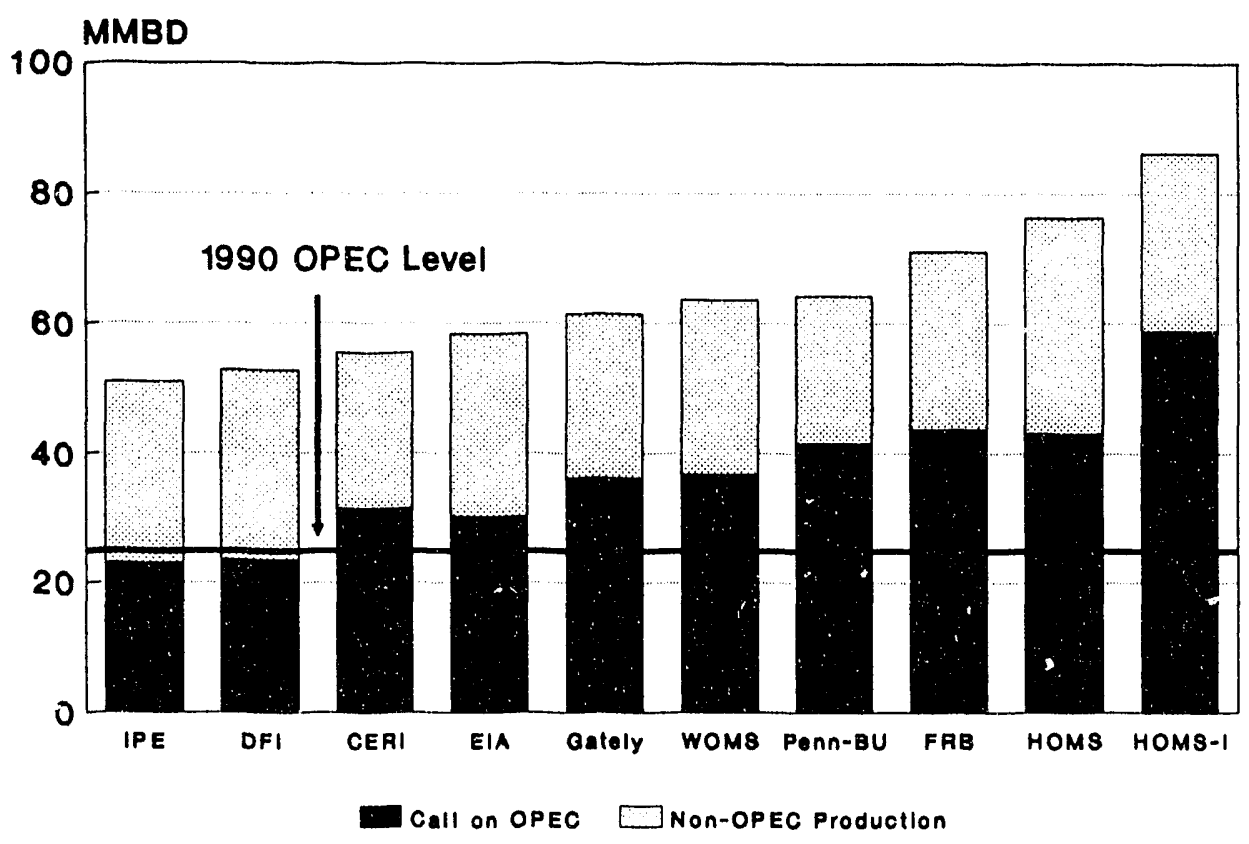

projected in the study rises to $56 \%$ in 2000 and $62 \%$ in 2010 in the 1989 IEO price case. Since market demands vary more across models than do non-OPEC supplies, differences in the call on OPEC will reflect differences in total demand more than in nonOPEC supply. Thus, the net call on OPEC in Figure 5 is some 50\% higher for HOMS and FRB-Dallas, even though they indicated the highest non-OPEC production in the previous figure.

\section{Growing U.S. Imports}

A rising OPEC market share reflects greater dependence upon imports for meeting oil consumption in many major energy-consuming countries. These trends are likely to accelerate interest in policies for reducing oil imports, particularly in the United Stares where low world crude oil prices and low U.S. taxes on oil use have exacerbated the oil import outlook.
Despite a wide range of projections for U.S. oil production and consumption, there is agreement that U.S. imports will grow briskly over the next two decades. Oil imports rise from 6.9 MMBD in 1988 to a range of $8-18$ MMBD by 2000 with the 1989 IEO price path (Figure 6). Imports tend to be higher in models projectin's greater U.S. and world demand growth in the right side of the figure) than with lower demand growth. In the 1989 IEO price case, slightly more than one of every three barrels consumed by the United States is imported beginning in 1988, but about two of three barrels consumed are imported by the end of the period, 2010.

\section{ALTERNATIVE PRICE PATHS}

\section{Is $\$ 19$ Oil Sustainable?}

Why couldn't the sustained, long-run oil price path remain flat at about $\$ 19$ (rising only with inflation) through the next two 
Figure 6. U.S. Imports in 2000 with 1989 IEO Price Path

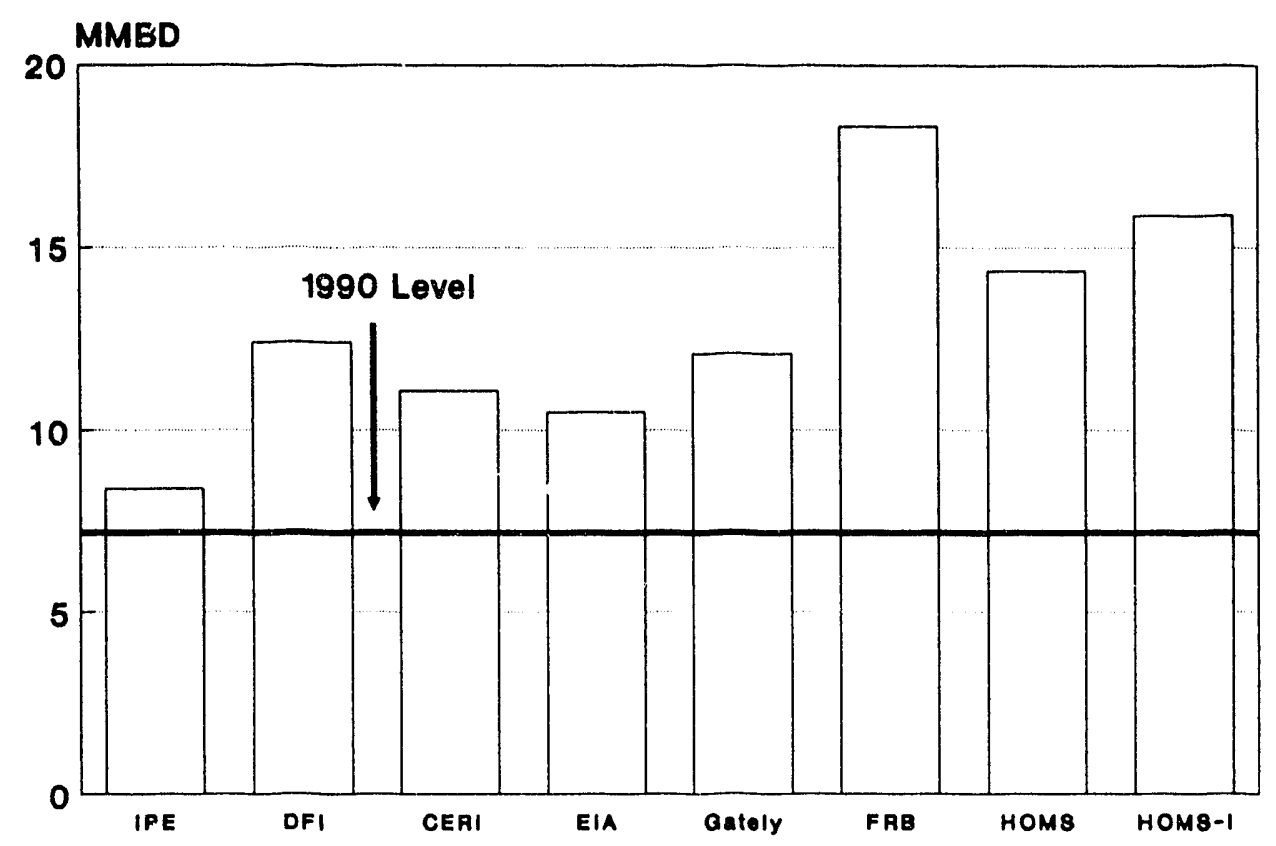

decades? ${ }^{9} \quad$ The long history of oil prices, dating back to early in this century, reveals no long-run trend towards rising prices after adjusting for inflation. Given that it has been just as likely for oil prices to decline as to rise in any given ycar, the current price may be the best estimate of the long-run trend given the extreme uncertainty about the market. Moreover, some analysts find that long-run resource costs are low enough and government policy is flexible enough to make this perspective a viable one. ${ }^{10}$

When oil prices are held constant at $\$ 19$ over the 1989-2010 period, the projected supply and demand levels in all models reveal strong pressures for OPEC members to either expand production rapidly or increase prices. This conclusion holds for a very wide range of demand projections in the various models and applies to three different economic growth scenarios. If OPEC were simply to meet this demand at the $\$ 19$ price, they would need to expand production rapidly, surpassing their peak production of $31 \mathrm{MMBD}$ well before the end of century. If world economic growth is to kecp pace with its recent trend (about 3\% per annum), three out of four barrels consumed in the market economies would originate from OPEC by 2010 .

The median results shown in Figure 7 for these three scenarios indicate substantially rising oil demands, modestly declining nonOPEC supplies, and rapidly growing dependence upon OPEC sources. Total market economies demand is shown as the sum of OPEC (the solid bar) and non-OPEC including net USSR exports (the light bar). Total demand in the base flat price case ${ }^{11}$ grows from 52 to 63 MMBD over the next decade. Due to modestly declining non-OPEC production, OPEC production would need to expand to $38 \mathrm{MMBD}$. The call on OPEC in 2000 would fall to $33 \mathrm{MMBD}$ if the market 
Figure 7. Production under Flat

Price Case with Base GDP Path

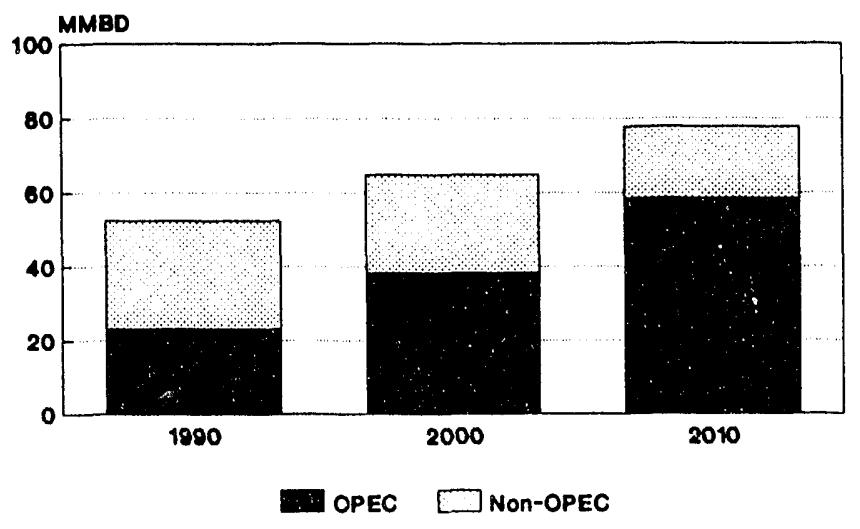

... with High GDP Path

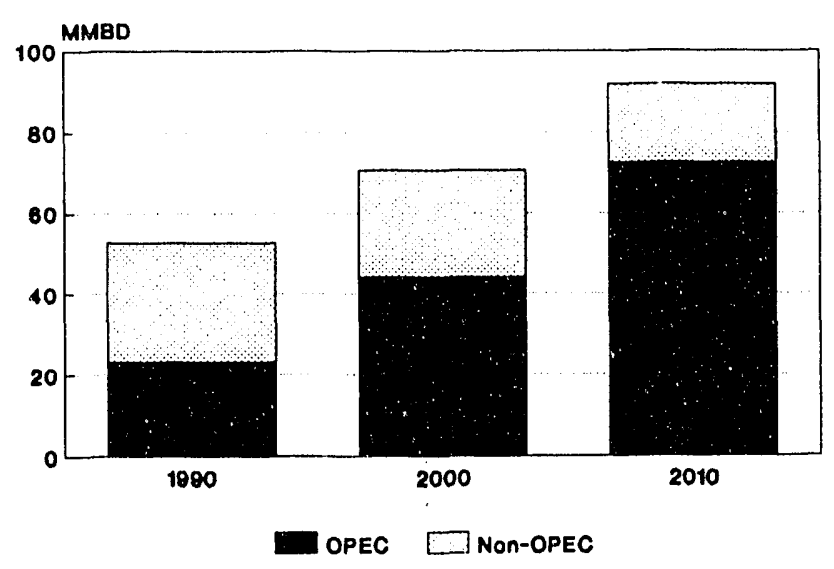

... with Low GDP Path

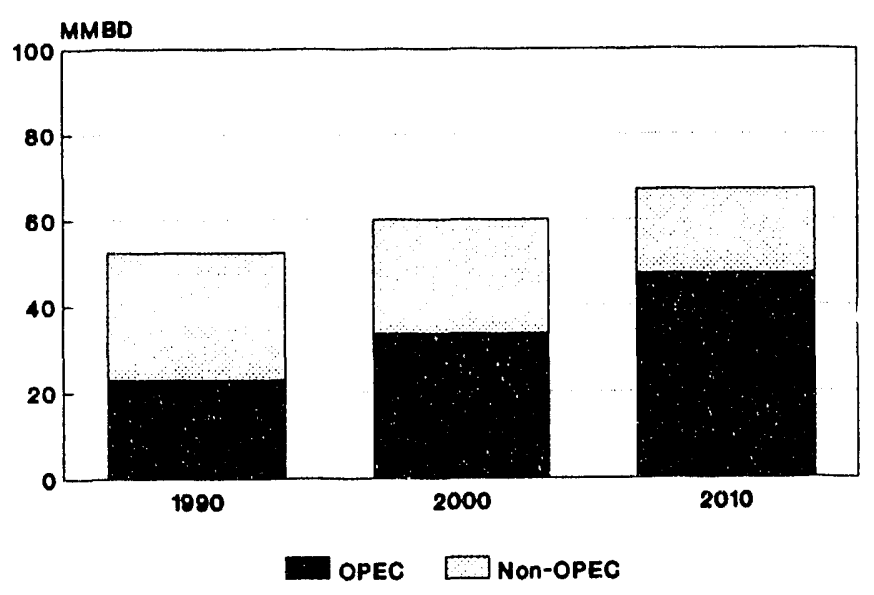


economies were to grow by 1 percentage point per year less (the low growth case); it would increase to 44 MMBD if these economies were to grow by 1 percentage point per year more. Expansions in OPEC supplies of 3.9, 5.2, and $6.7 \%$ per annum between 1990 and 2000 would be required in the low, base, and high GDP cases, respectively.

The sustainability of such an oil price path depends critically upon OPEC members' willingness to expand oil output. Oil productive capacity in the Middle East is relatively inexpensive and easy to expand. Indeed, even prior to the Iraqi invasion of Kuwait, announced expansions to OPEC capacity exceeded 10 MMBD. ${ }^{12}$ With the resolution of the Gulf crisis, many oil-producing countries seem willing for the moment to expand their capacity. If these developments should result in OPEC's capacity expanding to more than $40 \mathrm{MMBD}$ by 2000 , they would accommodate the demands on OPEC in the flat price scenario in all but the higher economic growth scenario. By 2010, however, oil prices would be under strong pressure to increase in response to world economic growth of $2.9 \%$ per annum, unless OPEC capacity was expanded to well over 60 MMBD.

OPEC might not increase production so quickly, requiring higher prices to reduce world demand and increase production outside OPEC. Economic incentives might well constrain cartel oil production from reaching such levels. Rapid expansion of its production could depress oil prices sufficiently to reduce the cartel's profits. ${ }^{13}$ Alternatively, OPEC's reluctance to supply additional oil could reflect a declining need for additional oil revenues for their internal investment, or a political resistance to depleting what they consider to be a "patrimonial" resource at "bargain" prices for the industrialized countries. The Energy Information Administration's 1989 International Energy Outlook, for example, projected that OPEC capacity would not exceed 36 MMBD hy 2000 . Under these conditions, OPEC's productive capacity would be severely strained by 2000 in two of the three economic growth cases.

In summary, prices could be sustained at $\$ 19$, but only with a program of aggressive capacity expansion by OPEC. In the absence of this acceleration in OPEC supplies, it becomes difficult to sustain this price path, particularly after 2000 . Even over the next decade, maintaining the flat oil price path through 2000 would require some combination of lower economic growth, higher production of conventional oil in areas outside OPEC, carly development of inexpensive unconventional oil supplies, and aggressive policies for reducing oil consumption by major consuming $\mathrm{cr}$ 'ntries. ${ }^{14}$

And firially, long-run developments within the Sovict Union could affect the long-run oil price path. While the bleak economic and political outlook portend declining oil exports over the next few years, a favorable resolution of these conditions could make the USSR an important source of additional world oil supplies in the longer term. The combination of expanded oil production, aggressive energy conservation, or extensive fucl switching away from oil within the Sovict Union could result in substantial increases in oil exports from this region in the coming years, placing downward pressure on prices.

\section{A Rising Price Path}

Without rapid expansion of OPEC supplies, it can be expected that oil prices will increase from $\$ 19$, augmenting non-OPEC production and reducing world demand and the call on OPEC estimated in the flat oil price case. Figure 8 shows the median projection for consumption, non-OPEC production, and the call on OPEC when oil prices are assumed to rise steadily from $\$ 19.50$ to $\$ 39$ through 2000 and remain at that higher level after 2000 . Consumption 
Figure 8. Production under Rising Price Case with Base GDP Path

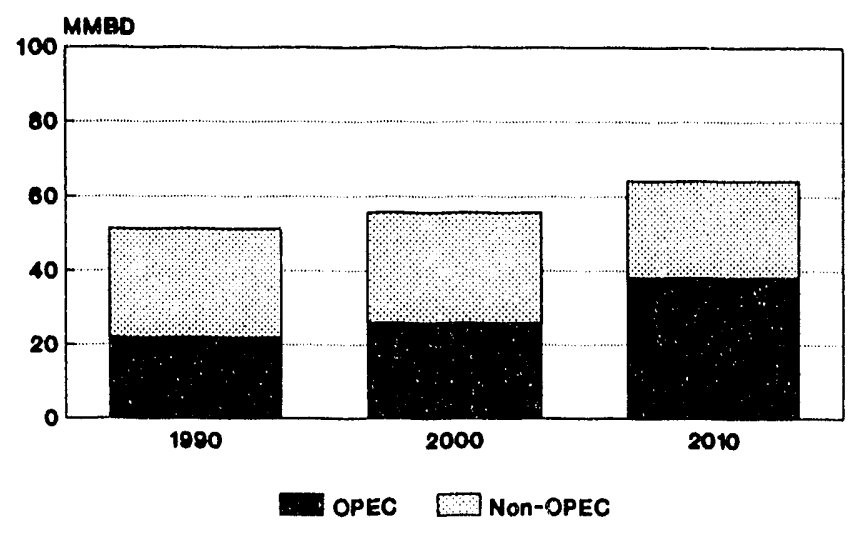

... with High GDP Path

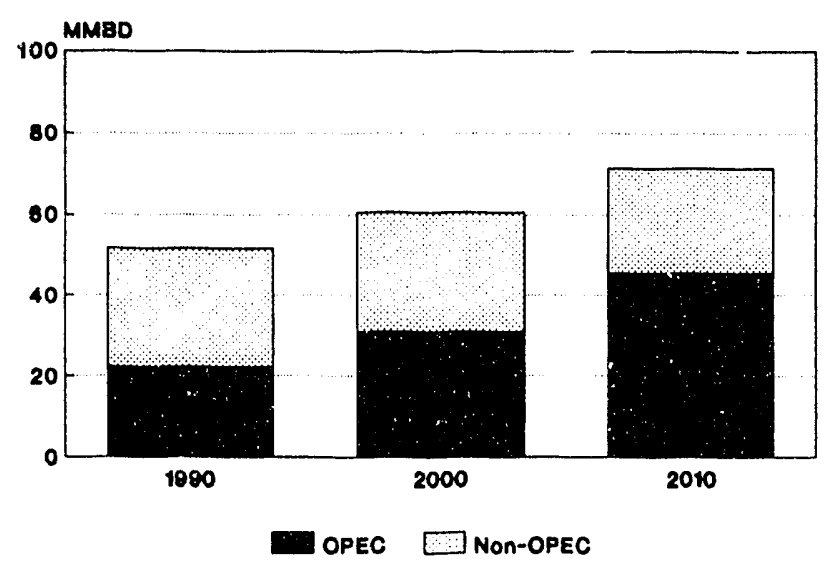

... with Low GDP Path

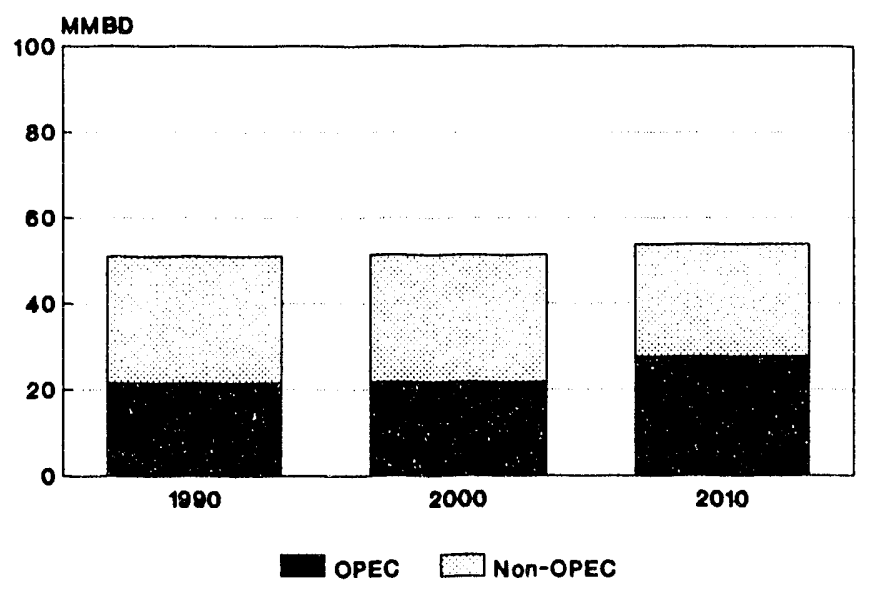


grows more slowly to 55 MMBD by 2000 , while non-OPEC production remains relatively stable at $28 \mathrm{MMBD}$ through the period. The higher prices significantly alter the call on OPEC, which falls from 38 MMBD in the flat price case to $26 \mathrm{MMBD}$ in the rising price case by 2000 . As a result, OPEC production increases by a relatively modest $1.7 \%$ p.a. through 2000 in the rising price scenario.

The rising price path represents an upper bound on oil prices over the next decade. While the call on OPEC lies in the 30-33 MMBD for four models, half the models show that OPEC members would be left with considerable excess capacity over this period. The median OPEC production is only $26 \mathrm{MMBD}$ in 2000 or $74 \%$ of the 35 MMBD capacity limit used by EIA. Moreover, higher prices in the presence of low OPEC output would be a strong inducement for cheating on production quotas by cartel members. These pressures become very intense when rising oil prices are combined with low economic growth, conditions which keep the median OPEC production virtually constant through 2000 and only modestly higher than current levels by 2010 .

The results from the flat and rising price paths help to determine the likely range of oil prices over the next decade. Flat oil prices below \$20 imply very strong growth in OPEC production; rapidly rising prices excecding $\$ 39 / \mathrm{Bbl}$ by 2000 require limited OPEC production in more than half the models. The 1989 IEO price path discussed previously lies between these two price paths over most of this period. ${ }^{15}$

\section{Reducing Dependence Upon OPEC}

These results also demonstrate that while oil production and consumption are moderately sensitive to oil prices, large changes in oil prices are often required to alter significantly the dependence upon OPEC suppiics. This finding is relevant to the effectiveness of policy intervention by non-OPEC countries to discourage oil consumption or encourage domestic production. Oil taxes increase the delivered price paid by consumers, oil subsidies increase the after-tax price received by producers, and oil import fees do both. Although mandated conservation measures (e.g., automobile efficiency requirements) do not increase delivered oil prices directly, they impose higher costs on consumers by requiring other inputs to be substituted for energy and hence can be viewed as an implicit tax on oil use.

Figure 8 implies that aggressive policy intervention by non-OPEC countries would reduce but not reverse their dependence upon Persian Gulf oil supplies compared to no new policies. Moreover, the strategy would be less effective than depicted here if some countries did not adopt the oil tax or tariff. Countries that did not adopt these policies would probably face a world price that was even lower than before the policy's implementation, thereby stimulating demand in these regions.

It will be especially difficult to avoid increases in U.S. oil imports. Figure 9 compares the median U.S. oil consumption and production in the flat $\$ 19$ case and in the rising price case (to $\$ 39$ by 2000 , flat thereafter). Higher prices clearly reduce oil consumption growth and slow the decline in oil production, but the need for imports grows. This happens despite a doubling in the U.S. price, which could increase due to a higher world oil price or to domestic U.S. policies that raise the price above world levels.

Thus, it will be difficult and costly to reduce imports enough to alter significantly the nation's exposure to oil imports or the insecurity of the world's oil supply. The removal of artificial barriers to domestic production and to energy conservation would clearly be desirable and would have beneficial effects. Huwever, appiopitiate policy responises should also include efforts to help the econ- 
Figure 9. Median U.S. Oil Demand, Supply, and Imports
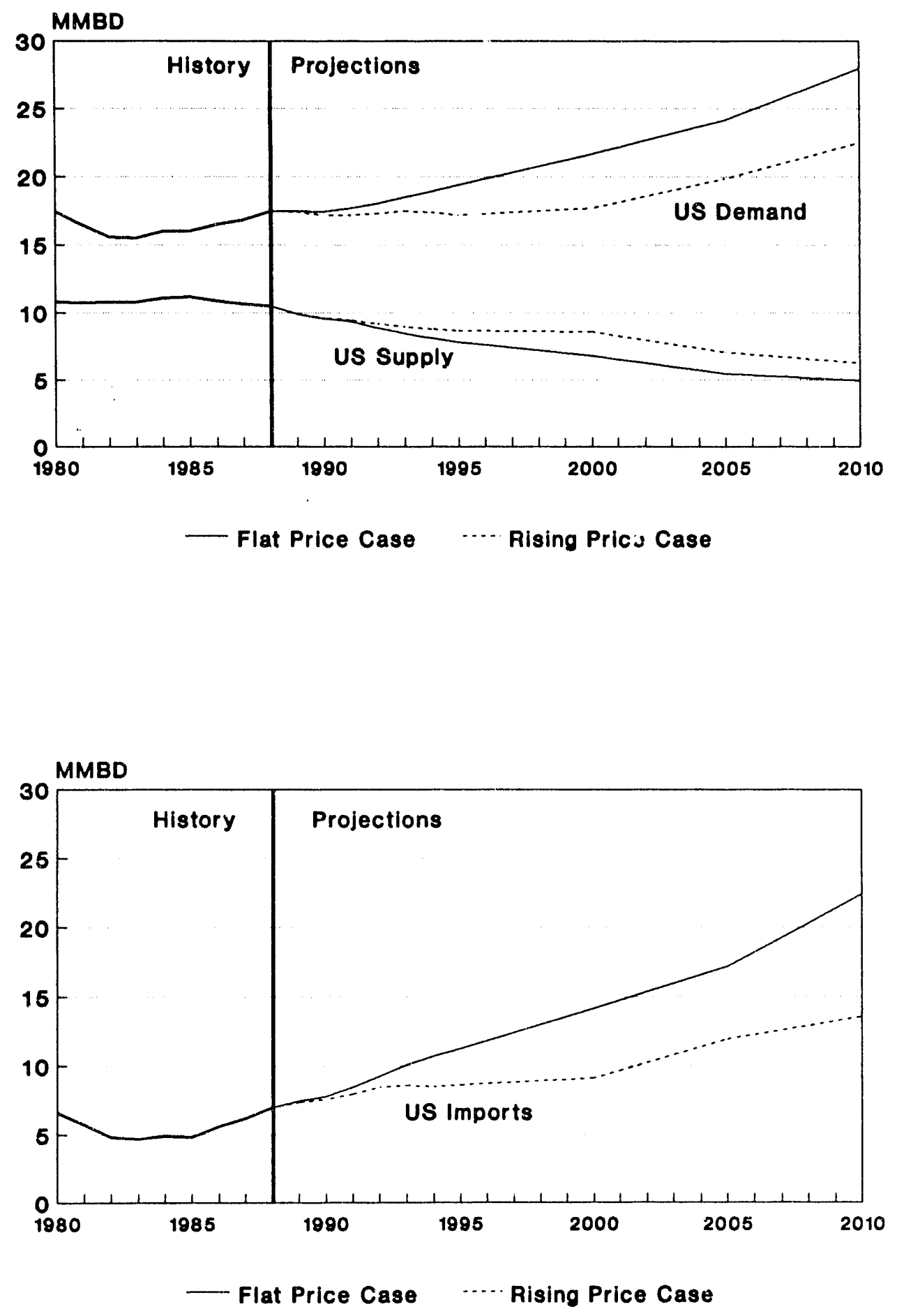
omy adapt to future price shocks. Such strategies might include oil stockpiles and macroeconomic stabilization policies.

\section{MARKET-CLEARING OIL PRICES}

The previous figures revealed the call on OPEC resulting from a predetermined price path used by all modelers. The supply and demand conditions projected by the model did not influence the of price path in these scenarios. In these estimates, OPEC was simply a passive producer, supplying all output left unmet by other producers, in order to keep prices along the assumed long-run, sustained price path.

We now ask a different question: would OPEC be willing to produce this amount and how would this output decision influence the market-clearing price in each model? Instead of fixing the price path and asking for the net demand for OPEC oil, the analysis now determines both the price and OPEC's production. In these scenarios, each model determines a unique market-clearing oil price path that balances the amount of oil supplied and demanded using some common assumptions about economic growth. It should be emphasized that these price paths result from standardized assumptions used by the modelers; their actual price projections based upon their own assumptions may well be different.

\section{Two Views of Future Oil Prices}

Figure 10 compares the oil price projections from each model when OPEC is assumed to exert some monopoly control, using the same economic growth assumptions as in the 1989 IEO price case discussed above (i.e., 2.9\% per annum in the market economics). ${ }^{16}$ All prices rise through the decade, but at considerably different rates. Six price paths generally lie above the 1989 IEO price path, while three others fall below it.

In combination with the previous discussion of the flat price scenarios, these results suggest that oil prices are unlikely to remain consistently below \$?0 per barrel over the next two decades. At the higher end, it is unlikely that oil prices will be sustained above the 1981 peak of $\$ 55$ (in 1990\$) reached temporarily during the second oil price shock. Within this wide range, uncertainty about external factors like world economic growth, oil supply and demand responses to prices and economic growth, and political developments in oil-producing and oil-consuming countries can lead to a number of plausible outcomes. Oil companies and energy policymakers should be prepared for a very wide range of oil prices. At the same time, our results also underscore that increased reliance upon Middle Eastern oil occurs regardiess $c$ the precise level of oil prices.

The emergence of two different general trends in the price path is clearly evident from this figure. Low demand growth and expanding OPEC output keep prices in CERI and DFI-CEC along a low-growth track, increasing to the low $\$ 20$ s by 2000 and to about $\$ 30$ by $2010 .^{17}$ This path is representative of the median response in the July 1990 International Energy Workshop poll reported by Manne and Schrattenholzer (1990). Rapid demand growth coupled with constrained OPEC output translates into sharply higher prices reaching the $\$ 40-\$ 55$ range by 2010 in HOMS and FRB-Dallas.

Although demands grow much more slowly in the remaining projections--Penn-BU, OMS, WOMS, and Gately--constrained OPEC production eventually forces prices upward. Across all models, when OPEC output is below about $35 \mathrm{MMBD}$, prices are always considerably higher than $\$ 30$ by 2010 in this scenario. Thus, low prices are associated with both low demand growth and expanded OPEC production. If either or both of these conditions do not. hold, substantially higher price result. Production outside OPEC could also contribute to price differences, but it varied by considerably less 
Figure 10. Market-Clearing Price with Cartel

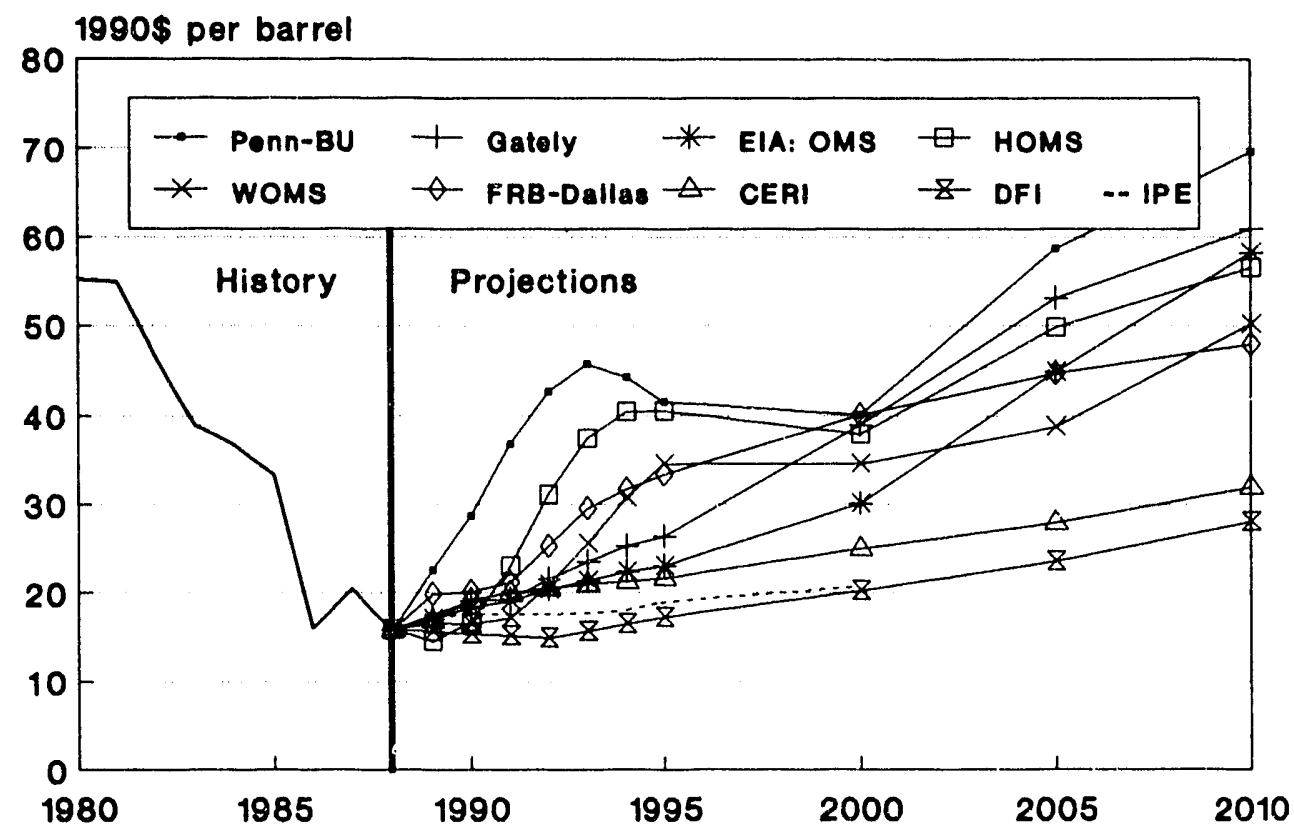

among models in this study than did total demand and OPEC production.

The expectation of some increase in oil price is similar to many earlier projections of oil prices made in 1980 and reflected in a previous Energy Modeling Forum study (1981). In hindsight, of course, these projections were very wrong, as oil prices fell dramatically. ${ }^{18}$ A principal difference between projections is that the previous estimates were made at a time when inflation-adjusted oil prices were some three times their current levels. The current projections are based upon the premise that after almost a decade of lower oil prices, the incentives for increased production outside OPEC and for energy conservation measures have been weakened considerably.

\section{Key Determinants of the Oil Price}

The critical role of world demand and OPEC production in influencing the market-clearing prices is shown in the three panels of Figure 11. The top panel duplicates the previous Figure 5. It emphasizes once again that high demands in the market economies in the 1989 IEO price case result in high calls on OPEC while low demands result in low calls on OPEC. When low calls on OPEC are combined with expanded OPEC capacity in the market-clearing price case (the middle pancl), low oil prices result (the bottom panel). These conditions apply to the DFICEC and CERI projections, both of which anticipate OPEC production to exceed 33 MMBD over the next two decades. ${ }^{19}$ As a result, there is less upward pressure on price, leading to relatively smaller increases in the oil price over the $1990-2010$ period.

The remaining models tend to project either higher world oil demands (and hence, calls on OPEC) or lower OPEC production under market-clearing conditions or both. ${ }^{20}$ Except for IPE, these models report higher oil price paths in the bottom panei. Prices 
Figure 11. Higher World Demands and Higher Calls on OPEC

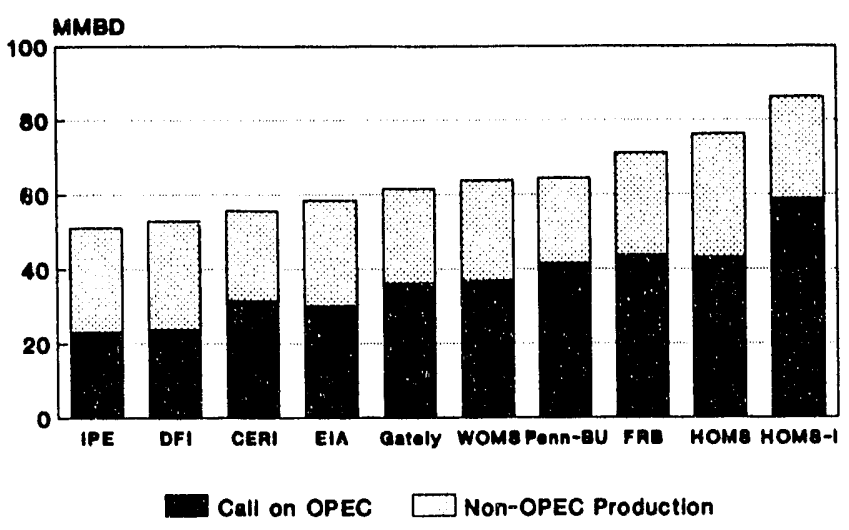

...or Constrained OPEC Production

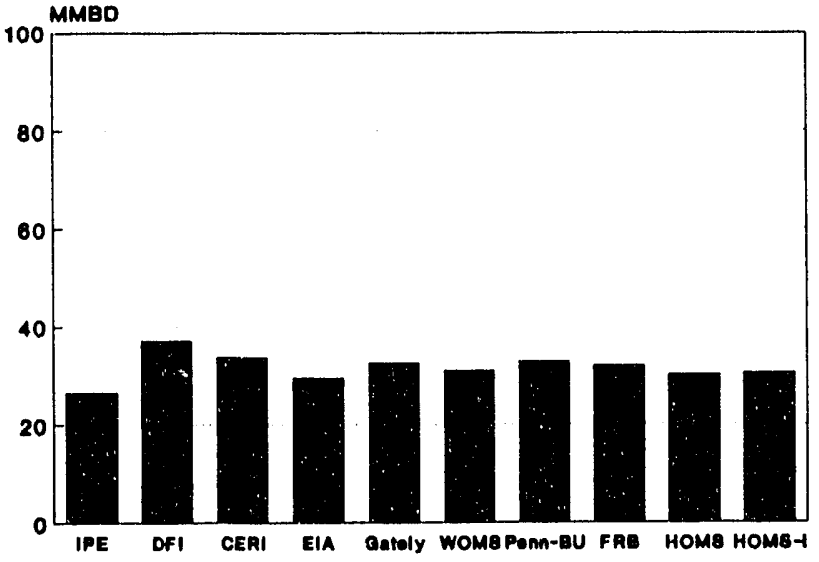

...Lead to Higher Market-Clearing Oil Prices in 2000

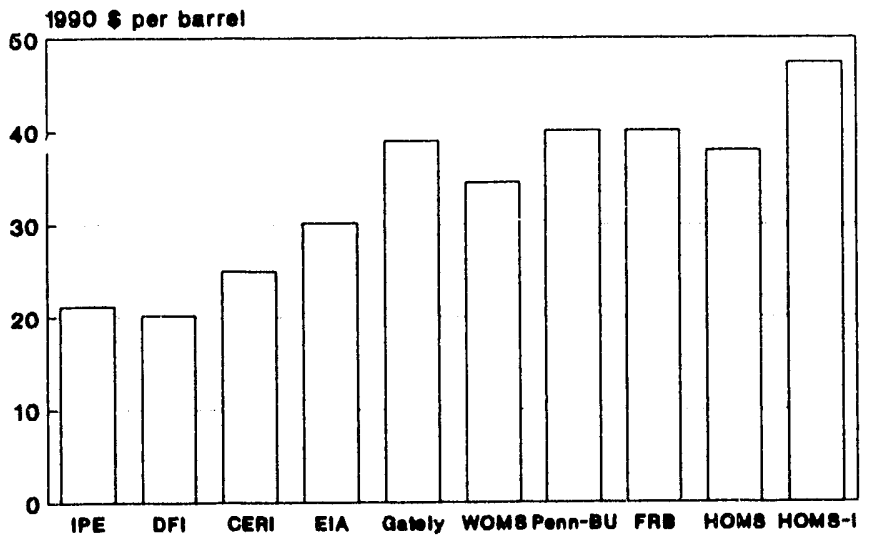


remain relatively low in IPE, even with limited OPEC production, because demand barely grows while non-OPEC production falls very little in that model. With even modest oil demand growth, OPEC production would need to increase in this model to keep oil prices from rising.

The cartel's output was not constrained in DFI-CEC and CERI by limits on OPEC capacity (about $37 \mathrm{MMBD}$ ). In these models, OPEC production exceeds this limit, thus contributing to their lower price paths. Except for Gately, ${ }^{21}$ the other models assume a capacity limit based upon the EIA's 1989 International Energy Outlook. This limit reflects one or more of the following economic and political conditions: declining net income (discounted) at higher production levels, limits on their use of additional oil revenues for internal investment, and a reluctance to sell more of a "patrimonial resource".

\section{FUTURE DEMAND GROWII}

This study has emphasized the key role of oil demand in influencing OPEC's rising market share, the increasing U.S. dependence upon oil imports, and the future path of market-clearing oil prices. It is important to understand the reasons behind the differences in oil demand observed in the study.

\section{Aggregate Oil Demand Projections}

The models in this study determine aggregate oil demand on the basis of assumptions on the oil price, economic activity (GDP), and technological progress. For example, the effect of oil prices on oil consumption depends upon the change in oil price and the response of demand to price. This demand response represents an aggregate measure of the effects of many decentralized decisions, such as the purchase of energyusing equipment and the intensity of use of equipment in many different sectors. It increases over time to reflect the greater substitution opportunities as new equipment replaces old equipment. Although the oil price and GDP paths were standardized across models in nine scenarios, the responses to these variables may differ considerably because modelers determine different values for these effects.

It is understandable why modelers do not agree on the relative importance of different factors for explaining oil demand, even when they use the same oil prices and GDP paths. Energy analysts, policymakers, and planners must draw lessons about how these factors affect demand from a limited historical experience that includes several sharp shifts in oil market trends. Over the last three decades, oil demand has gone through three distinct stages. Prior to 1973, demand grew briskly while prices remained relatively stable at below \$10 per barrel (1990\$). During the 1970) and through 1985, demand was sluggish while prices remained high and economic activity slowed. In the last half of the 1980s, demand grew slowly at first but eventually recovered strongly while prices generally remained low and the economy expanded.

This situation provides no clear criteria for distinguishing the one "correct" explanation for the decoupling of oil demand and economic growth. For example, the slow growth in oil demand during the mid-1980s, coupled with low energy prices, can be explained as a gradual adjustment in energy demand in response to the high prices of the late 1970s through the early 1980s. Alternatively, the same conditions can be explained as a relatively low response to price and a gradual reduction in oil use through technological progress independent of oil prices. 


\section{Major Influences on Demand}

A framework for explaining these differences in demand behavior can be used to separate the oil demand growth into several components:

(1) the "GDP growth" effect reflecting the influence of higher levels of economic activity;

(2) the "price" effect resulting from future changes in the price of oil;

(3) the "autonomous efficiency improvement" effect in which changes in oil use accrue over time and are unrelated to either price or GDP changes; and

(4) the "initial momentum" effect due to the fact that current oil demand has not adjusted completely to current and past oil prices.

The first two effects are relatively well known and are universally accepted by oil analysts. More GDP growth and lower oil prices stimulate oil demand growth. Analysts disagree, however, on the strength of these two responses. The remaining two effects require some elaboration.

"Autonomous efficiency improvements" (AEI) refer to changes in oil use that are not motivated by oil price changes. For example, in 1967, Boeing introduced the 747 airplane, which yielded enormous fuel efficiency gains. Higher energy prices did not induce the adoption of this technology; the plane had been designed well before the oil price shocks of the 1970 s for a variety of reasons. The gradual turnover in the fleet of airplanes that reduced this sector's oil intensity would have occurred regardless of what happened to oil prices.

Shifts in the economic structure away from eneryy-intensive sectors and products can also contritbute to a long-run declinc iñ oil use per unit of output in many developed countries. To the extent that the shifts are not induced by price changes, they can be considered as part of the autonomous efficiency improvement effect.

"Initial momentum" refers to the tendency of oil demand to either increase or decrease in the absence of future price or GDP changes and autonomous efficiency improvements. The major source of initial momentum is the incomplete adjustment of current oil demand to current and past oil prices. Since energyusing equipment is replaced only gradually, future oil demand will be adjusting to the current oil price, even if there are no future changes in the oil price. For example, in 1981 the momentum effect would have been negative; if price had stayed at its high 1981 level, the lagged effects of adjustments to previous price increases would have reduced demand, as more energy-efficient capital was adopted. By contrast, the decline in oil prices in 1986 pushed the real costs of many petroleum products below their levels over most of the last two decades. If these lower oil prices persisted indefinitely, there would be less incentive to pursue energy conservation in new investment than before. New equipment would become more energy intensive than the equipment installed previously, causing the economy's energy intensity to rise over the next several years. This would be a positive momentum effect. In other words, the lagged effect of past prices on future consumption means that oil demand changes even if there were to be no future change in oil prices or economic activity. 22

These last two effects--autonomous efficiency improvements and initial momentum-can have a significant impact on future oil use per dollar of GDP (or oil intensity). The lower line in Figure 12 represents the lower demand path found for most models in this study when the inflation-adjusted oil price is held at its 1988 leve! over the next two decades. Oil intensity declines as tech- 
Figure 12. OECD Oil-GDP Ratio in Flat Price for Two Different Demand Trends

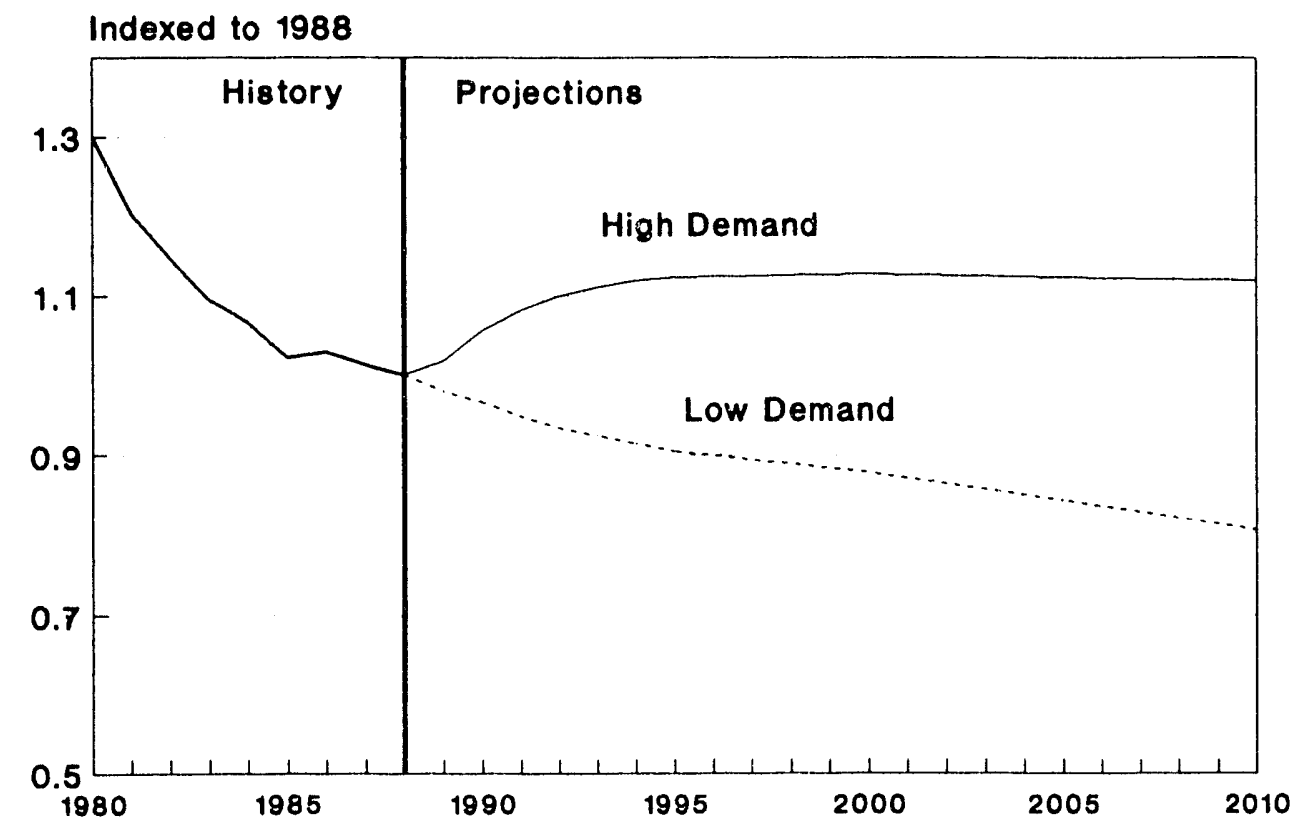

nological progress and shifts in the cconomy's structure improve oil efficiency over time. Moreover, price declines prior to 1988 have little or no effect on future oil demand. Oil intensity continues its downward drift, although at a slower rate than in the early 1980 s, immediately after the second oil price shock.

The upper line shows the higher demand projection of a few models for the same flat oil price path. Autonomous improvements in oil efficiency are absent in these projections. Moreover, they assume that the oil price declines in 1983 and 1986 begin to stimulate oil demand gradually as new energy-using equipment is purchased. In the absence of further oil price changes (after 1988), oil demand would eventually begin to increase faster than economic growth, as shown for the 1990-95 period in Figure 12.

There will be other effects on oil demand that fall outside these definitions and are considered part of the initial momentum effect in the decomposition of oil demand growth. Some regulations, such as the corporate average fuel-efficiency (CAFE) standards for automobiles in the United States, may require consumers to purchase more fucl-efficient vehicles than they would otherwise choose. Alternatively, reductions in oil use can also be achieved through interfuel substitution towards other fuels. If, for example, a relative abundance of natural gas depresses that fuel's price significantly below its historical relationship with oil prices, oil demand would fall even in the absence of oil price increases or autonomous efficiency improvements. ${ }^{23}$

\section{Decomposition of Demand Growth}

The causes for discrepancies in the projections for oil demand growth have been separated into the above four components, based upon the results from four different scenarios. $^{24}$ In each of the four scenarios, all modelers assumed the same oil price and 
GDP paths. Hence, differences in the estimated price and GDP components reported in this section reflect differences in the responses of oil demand to the assumed changes in price and GDP.

Figure 13 summarizes this decomposition of the oil demand growth for the OECD countries over the 1988-2000 period in the 1989 IEO price scenario. The solid line indicates the total change in oil demand above its 1988 level of 37 MMBD. Total demand growth is comprised of four separate effects, some of which increase growth while others decrease it. The models are ordered according to total oil demand growth, with the lowest growth to the left and the highest growth to the right.

Major discrepancies exist among these demand projections. The rapid growth in the two HOMS and the FRB-Dallas projections are striking. OECD demand grows from about $37 \mathrm{MMBD}$ in 1988 by $13-14 \mathrm{MMBD}$ to $50 \mathrm{MMBD}$ or more by 2000 . At a minimum, an $8 \mathrm{MMBD}$ gap separates this group from the other projections, in which demands grow by 5 MMBD or less to no more than 42 MMBD by $2000 .^{25}$

The models showing the highest demand growth--Gately, WOMS, FRB-Dallas, HOMS, and HOMS-1--use demand responses to prices and economic growth that have been statistically derived from the historical experiences of the last several decades. While future demand responses emulate past ones in these models, projected demand trends can still differ from past ones, depending upon the assumed future conditions for the oil price and economic growth. In contrast, all of the remaining models except BP America use demand responses to these conditions that are based upon the modelers' judgement. ${ }^{26}$

Interestingly, large discrepancies in oil demand projections for 2000 remain even after accounting for differences in the demand response to future oil prices. Across projections, the GNP effect varies the most, but the variation in the price and the initial momentum effects are also significant. $^{27}$ The contribution of the initial momentum effect is surprising and unexpected. As early as 1995, this effect accounts for about 5-6 MMBD of the 13 MMBD increase in total demand in HOMS and FRB-Dallas. ${ }^{28}$ Even after five more years of economic growth, these momentum effects are large relative to the GDP effects for the OECD demand growth estimates shown in Figure 13. In these two models, they account for about 30 percent of the total growth in the flat price scenario (i.c., excluding the price effect).

Within each projection, the biggest component is the effect of higher GDP in stimulating oil demand, although the initial momentum and price effects are substantial in a few models. The price effect increases over time as energy-using equipment is replaced by more energy-efficient vintage 's, but the economic growth effect remairim dominant, even over the longer 1988-2010 period.

HOMS and FRB-Dallas project long-run oil intensities as a function of the oil price only. ${ }^{29} \mathrm{~A}$ one percent increase in the GDP level will result in a one percent increase in oil demand, if oil prices remain fixed at their 1988 level. There is no autonomous improvement in oil efficiency (labeled as "trend effect" in Figure 13) that operates independently of the oil price in these two models. While some new technologies save energy, other technologies and lifestyle changes may actually use more energy. Higher prices dampen but do not offset this larger demand growth.

The presence of autonomous improvement in oil efficiency keeps projected oil demands considerably lower in BP America, ETAMacro and WOMS, even though all possess relatively large GDP effects. Moreover, the price effect is considerably larger in ETA- 
Figure 13. OECD Demand Growth, 1988-2000: Decomposed into 4 Effects

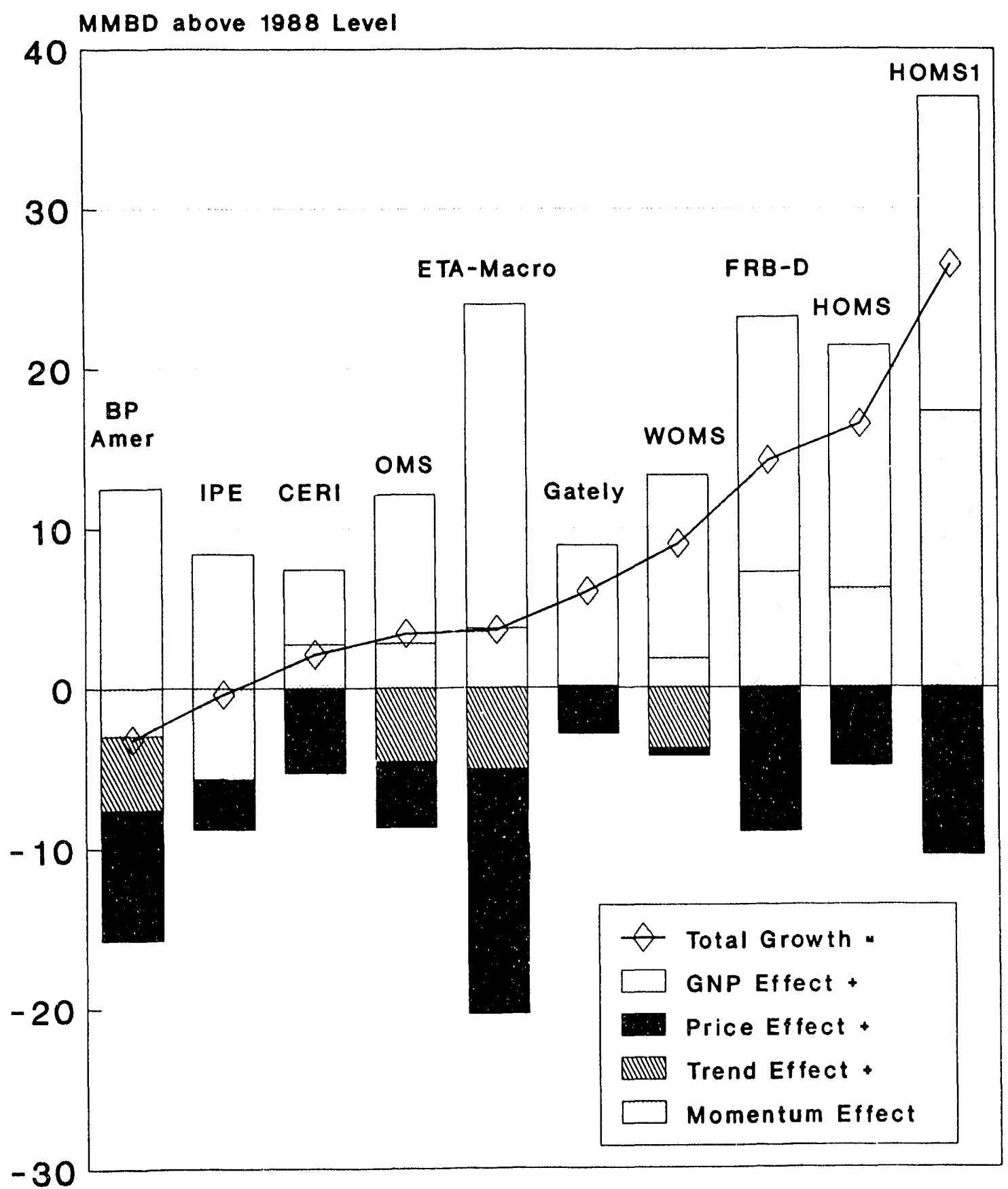

Note: Growth in 1989 IEO Price Path 
Macro than in other models. Without this price effect, its oil demand is comparable to the highest demands (HOMS and FRBDallas) in the flat price scenario. ETAMacro focuses upon all energy forms. When oil prices rise, oil demand falls as: (1) the demand for all energy declines, and (2) as electricity replaces oil and other fossil fuels. In ETA-Macro, this first effect alone is comparable in size to the full effect of oil prices on oil demand in most of the other models, resulting in greater sensitivity to oil prices.

The remaining models--IPE, CERI, Gatcly and OMS--have relatively small GDP growth effects, in which oil consumption grows proportionately less than economic growth. This smaller GDP effect operates like the trend effect in the other models; oil efficiency improves over time (assuming some economic growth) even if oil prices do not increase from their 1988 levels. OMS also reports an additional autonomous trend towards increased oil efficiency that further reduces its projected growth in oil demand.

The initial momentum effect is pronounced in the HOMS and FRB-Dallas projections because long-run oil intensities in these models respond symmetrically to oil price increases and decreases. Moreover, oil intensities respond quite slowly to oil price changes. The model parameters indicate that much of the response to the recent lower oil prices had not occurred by 1988 . Since the oil price is currently lower than it has been over much of the last 15 years, the initial momentum effect in most models causes oil demand to grow, i.e., it is positive. Even if there were no economic growth, under constant prices OECD demand would still have grown over $6 \mathrm{MMBD}$ in HOMS and FRB-Dallas simply due to future demand adjustments to the current oil price level.
Incomplete adjustment to current and past prices plays a relatively minor role in most of the remaining models, accounting for at most 3 MMBD of demand growth by $2000 .^{30}$ The negative initial momentum component for two models (BP America and IPE) is not due to the incomplete adjustment of current oil demand to current prices, as in the other models. For example, continued automobile efficiency improvements are allowed in the BP America model regardless of the oil price path. This decline arises from policies for fuel efficiency standards on oil use and are unrelated to either price or autonomous efficiency improvements.

The historical experience of the 1970s and 1980 s imposes certain restrictions on the nature of the oil demand response that are reflected in the model responses shown in Figure 13. First, large price effects are generally associated with large GDP effects, and small price effects with small GDP effects. A model with a large response to GDP and a small response to oil prices would have badly overestimated oil demand growth over the last two decades, given the actual oil price and economic growth trends over this period. Similarly, one with a small response to GDP and a large response to oil prices would have underestimated oil demand growth over this same period.

Second, the autonomous efficiency improvement effect is often absent in models displaying large price effects. Past reductions in oil demand intensity can be due to changes in price and other nonprice factors. When a model attributes a major role to price, there remains little additional improvement in energy efficiency to be explained by nonprice factors.

And third, large price effects are often associated with large initial momentum effects and vice versa. This is understand- 
able because the initial momentum effect is itself a response to price changes from previous periods. If demand responds symmetrically to price increases and decreases, these two effects incorporate similar responses. $^{31}$

\section{FUTURE CHALLENGES FOR WORLD OIL MODELING}

The working group has used existing models of the world oil market to quantify certain key relationships important for understanding this market and to highlight major areas of agreement as well as differences. By providing a consistent framework for evaluating a number of important factors, the models have helped to reveal the implications of various oil supply and demand trends for future oil prices and dependence upon OPEC supplies.

While the models have been very useful for advancing the group's discussion, they are not without their limitations. In many cases, the models reflect what we can quantify about the oil market. Their limitations are often indicative of limitations on our general understanding of oil markets themselves.

\section{Basic Approach}

Many world oil models emphasize long-run demand trends and responses to price and economic growth. Traditionally, they have been less developed on the supply side for understandable reasons. It has been more difficult to incorporate factors like the distribution of resources by cost category, the impetus for technological advancements in oil drilling, and producer-country tax and royalty policies. Similarly, both modelers and other oil experts have difficultics in articulating the cartel's long-run strategies on capacity expansion.

As a result, the models' projections are often driven by a few key assumptions: the rate of economic growth, an estimate of the recoverable resource base outside of the cartel, and the cartel's capacity path. With modest economic growth, oil prices will be projected to rise over the next two decades given the conventional view on trends in oil use efficiency, the non-OPEC resource base, and OPEC capacity.

The models were not developed for analyzing very short-run issues, such as energy shocks and energy security policies. These topics require information on monthly or quarterly rather than annual market conditions as well as rather extensive linkages between the oil market and the macroeconomy, incorporating both short-run and long-run effects. Other analytical frameworks have been developed for addressing these concerns.

Morcover, these annual projections seldom extend beyond 20 or 25 years, limiting the ability of these models to incorporate a range of longer-run considerations, such as the transition to alternative liquid fuels for transportation or the longer-run effects of environmental policy on world oil markets. Extending these projections even another 10 years may require some fundamental changes in model structure and data requirements to incorporate some of the technological, lifestylc, and other changes that are likely to emerge in a longer period. The longer time horizon may also highlight the need for models that have producers and consumers consider the impact of future conditions on current decisions.

\section{Recommendations for Future Research}

The working group identified four critical areas where further developments would be particularly useful for improving the state of analysis of world oil markets.

OPEC Capacity. The most critical challenge to future modeling appears to be ways to represent the cartel's long-run output deci- 
sion. Decisions about when and by how much the cartel will expand capacity need to be linked to the market conditions being determined elsewhere in the model. (IPE and Penn-BU already incorporate some of these effects.) In their current form, most world oil models are critically dependent upon assumptions about the future path of OPEC capacity. Once target capacity levels are reached in these models, oil price projections become extremely sensitive to key input assumptions on economic growth and OPEC capacity. Another important dimension would be to incorporate the possibility of rivalry within OPEC and its impact on long-run capacity decisions.

\section{Oil Demand Within and Outside the OECD}

Countries. Another critical concern is to resolve the disparate views on future trends in oil use efficiency. Additional study is needed to separate the effects of current prices from past prices and other nonprice factors such as technological progress or shifts in the economy's composition of goods and services. World oil modeling should also include efforts to differentiate the demand for oil as a transportation fuel and all other oil uses outside the transportation sector. In addition, most analysts expect oil demand growth to be concentrated in the developing countries. Poor data often prevent careful analyses of these regions, resulting in crude assumptions made about their demand responses to changing market conditions, often without explicit consideration of structural change in the economy and its impact on the transition from traditional to commercial energy. Moreover, few existing world oil models explicitly represent the interactions between energy use, energy production, capital formation, and international trade. As a result, balance-of-payment constraints on future commercial energy use are frequently ignored.

Interfuel Substitution. Many existing models focus on oil only, giving limited attention to interfuel substitution issues. They implic- itly assume that other fuel prices move with oil prices and that interfuel substitution responses will be as they have been in the past. Environmental policies and more abundant natural gas supplies can alter both of thes: relationships, dramatically changing the oil market picture. Natural gas can be converted to close substitutes for oil, such as compressed natural gas and methanol to fuel vehicles. It can also be used to replace oil for power generation. While the models cannot incorporate all the technical and economic factors that may influence these decisions, some capability to handle these broader types of issues will become increasingly important.

Non-OPEC Resources and Supply. Analyses of world oil market conditions are severely limited by the unavailability of reliable data on the cost of producing oil in major supply regions outside the United States. Geologic estimates of the remaining resource base are useful but do not reveal the relative costs of exploring for and finding oil resources in different regions. Reliable drilling cost information is collected primarily for the United States but remains unavailable for other regions. This problem is compounded by the absence of a market mechanism and an effective pricing system within the Soviet Union, currently the largest oil-producing country in the world. And finally, the role of technology and the effect of producingcountry tax policies in enhancing future oil supplies is poorly understood.

\section{CONCLUSIONS}

For what kind of world oil future should energy policymakers and corporate decisionmakers be preparing and planning? Our results strongly suggest a wide range of possible outcomes. Some analysts see rapidly growing demand pushing up against limited OPEC capacity, conditions leading to rapidly rising oil prices later in this decade. Other analysts expect slower demand growth 
combined with increased OPEC willingness to produce oil, conditions leading to quite modest increments in the oil price. Over the next decade, oil prices in inflation-adjusted terms are unlikely to be sustained above 1981 peak levels temporarily reached during the second oil shock. Nor are they likely to fall below current (\$19) levels for an extended period of several decades, unless the cartel disintegrates or unconventional oil becomes economic much sooner than is currently anticipated.

Despite the rather substantial differences in views on oil supplies and demands, there was agreement within the study on certain aspects of the oil market futurc. Fueled by greater demand growth, particularly outside OECD, oil production will need to expand significantly. As a result, production will be increasingly concentrated in the lower-cost regions of the Persian Gulf. This result applies across a wide range of possible future oil price paths or rates of growth in oil demand. A greater dependence upon these oil supplies will increase the impact of economic and political decisions within the Middle East on world economic growth. Moreover, increased demand for the cartel's oil will increase its market power, increasing the likelihood that coordinated strategies among cartel producers will be successful in keeping oil prices above those expected in a pure competitive environment.

Oil imports in many OECD countries will rise. This dependence will be more acute in the United States, where the combination of steady growth in oil use and falling domestic production is expected to increase the import share of total consumption from $38 \%$ in
1988 to $50 \%-60 \%$ by 2000 even with gradu ally increasing oil prices. If oil prices were to remain unchanged at about $\$ 19$ (in inflation-adjusted tern's), the United States would be importing about two of every three barrels consumed by the end of the century. Thus, the United States will be faced with either high prices and low imports or low prices and high imports; either way, the oil import bill as a percentage of total GDP will rise.

There remains considerable uncertainty about the future geopolitical environment in the Middle East in the aftermath of the war between Iraq and the allied forces. While the long-run implications of rising dependence upon Persian Gulf oil production are not yet fully understood, such trends are likely to thrust encrgy security concerns back before policymakers in many oil-consuming countries. There is likely to be more active consideration of policies that reduce the dependence upon oil, thereby limiting these econor-ies' vulnerability to future oil price shocks. Ilowever, there are limits to how aggressively and how quickly the world economies can reduce their dependence upon Persian Gulf oil before import-reduction policies begin to impose large economic costs. While import-reduction policies should be pursued, they should also be supplemented with policies that help their economies adapt more easily to sudden energ; price shocks. Examples of such "shock absorbers" include monetary and federal tax policies for stabilizing the economy, increased wage and price flexibility in their economies, and the building and use of oil stockpiles. 
APPENDIX

Methodology for Decomposing Demand Growth

The four scenarios specified oil price and GDP paths that were to be used by all models. The cases included: (1) the 1989 IEO price case (with the baseline GDP path); (2) the flat price case (with baseline GDP); (3) the flat oil price path with no economic growth after 1988; and (4) the flat oil price path with no economic growth and no technical change unrelated to oil price changes. The price effect was measured as the change in oil consumption between the first two cases; the income effect was measured as the change in oil consumption between the second and third cases; and the autonomous efficiency improvement effect was measured as the difference between the third and fourth cases. The initial momentum effect was measured as the change in oil consumption between 1988 and 2000 in the fourth scenario. Algebraically, the growth in demand in the 1989 IEO price case equals the sum of these components:

$$
\begin{aligned}
D(t, \text { IEO }) & -D(1988)= \\
& D(t, \text { IEO })-D(t, F l a t) \\
& +D(t, F l a t)-D(t, \Delta Y=0) \\
& +D(t, \Delta Y=0)-D(t, \Delta Y=\Delta T=0) \\
& +D(t, \Delta Y=\Delta T=0)-D(1988)
\end{aligned}
$$

where $D$ is oil demand, $t$ is year (e.g., 2000), and IEO, Flat, $\Delta Y=0$, and $\Delta Y=\Delta T=0$ refer to the four cases. The four right-hand terms are the price, GDP, autonomo ss efficiency improveinent, and momentum effects, respectively. The sum of the last three effec ${ }^{\star} s$ equals the aemand growth in the flat price case. BP America's price effect may be overstated slightly because it is for the rising piice case rather than the 1989 IEO price case, which was $n$ t simulated for this model. Dertands for DFI-CEC have not been decompc ed, because they are the OMS projections by assumption. Pcan-BU did not sepirate OECD demand from world demand. 


\section{ENDNOTES}

1. Those interested in long-run energy and oil projections are referred to the semiannual polls conducted by the International Energy Workshop (IEW), as reported by Manne and Schrattenholzer (1989).

2. This general desiription does not apply to DFI-CEC and ETA-Macro, which report market outcomes every 5 or 10 years. Market participants in ETA-Macro seek the single best strategy for obtaining the most value (discounted) from their consumption of all goods and services over many years, wither than responding to current prices aione. Oil producers in DFI-CEC seck the sing!e strategy for realizing the most net incorne (discounted). Both models assume thxai oil producers and/or consumers know fut die market outconses with certainty (perfect foresight), have the flexibility to act on this knowk tge. and are not influenced by other noreconomic objecives. In addition, there are other $\left.n^{\prime}\right) t e w$ sithy exceptions to the general framework described in this section. BP America, ETA-Macro, and Penn-BU represent inter $f_{\mathrm{h}} \mathrm{al}$ substitution opportunities explicitly; Penn-BU incorporates the effect of shifts in economic structure on oil demand; IPE and Penn-BU allow market conditions to influence OPEC capacity; and CERI and Gately choose OPEC production paths rather than capacity to represent OPEC's long-term investment strategy. Each model is described in Kress et al (1990). The responses of supply and de. mand to price and income changes inferred from various scenarios are presented in Huntington (1991).

3. The complete scenario input specifications are described in Huntington et al (1989).
4. The total resource base, including undiscovered resources yet to be classified as proven reserves, is less concentrated, but the Middle East still accounts for more than half.

5. Half the model projections lie above, and half below, the median value.

6. Total production is differentiated by OPEC and non-OPEC sources in this study because the models have reported production from OPEC countries as an aggregat.. In discussing the issue of dependency, however, we have inferred Persian Gulf production from the scenario results as the difference between reported OPEC output and some external production estimates for other OPEC member countries. The latter were based upon some Energy Information Administration estimates in the nternational Energy Outlook.

7. This conclusion was reached in a previous Energy Modeling Forum study (1987).

8. Net USSR exports could become an important new supply source and represent a significant uncertainty in any oil market outlook. In the current study, however, these exports do not vary much across models and therefore do not contribute importantly to differences between models in the projected call on OPEC.

9. The flat oii price path was specified as $\$ 18$ in constant $1988 \$$, or $\$ 19.44$ in $1990 \$$ using a conversion factor of 1.08. To avoid the false impression of precision, we discuss the flat oil price trajectory in terms of a constant $\$ 19$ price in the remainder of the report. 
10. Adelman (1986) argues against a longrun trend towards increasing costs. Oil prices will increase or decrease depending upon the relative strengths of competitive and monopolistic forces, but resource depletion will not push the long-run price trend upward. See also Lynch (1989).

11. The base flat oil price case assumed the same GDP growth rate as in the 1989 IEO price case.

12. As reported by Lynch (1990), Table 3, p.8.

13. Whether the cartel's net revenues would decline depends upon the response of world demand and of supply outside the cartel countries to price, which countries comprise the cartel, and what share of the total market these countries supply.

14. Many of these possibilitics are discussed in greater depth in the forthcoming technical volume for the current EMF study.

15. This price path reaches the rising price path by 2010 .

16. The study has not analyzed the important but difficult issue of which OPEC countries might constitute the oil-producing cartel. A high economic growth and a competitive case were also simulated. In the latter, oil prices were modestly lower than in the cartel case (e.g., by $\$ 10$ per barrel) in some models and substantially lower, with levels ranging in the $\$ 10-\$ 20$ per barrel, in others. This scenario demonstrated that analysts had very different approaches for representing a competitive world oil market.

17. IPE joins this group through 2000 , but does not project oil market conditions after 2000. The reasons for its lower price path are discussed later in the text.

18. A substantial portion of the error in projecting oil prices in this previous EMF study was due to external assumptions about economic growth and the non-OPEC oil resource base. World economic growth was slower and non-OPEC production higher than anticipated by many experts. Another important error was to overestimate the amount of demand-adjustment that had already been accomplished by 1980 , in response to higher prices. These points have been addressed by Gately $(1984,1986)$ and are discussed briefly in the forthcoming technical volume for the current EMF study.

19. The expansion in OPEC production in these two models is more pronounced for 2010 than for 2000 (shown in Figure 11). The results for 2010 are discussed in the forthcoming technical report for this study.

20. Similar results are obtained for other years, e.g., 2010. While this simple explanation is extremely powerful for sorting through differences in projected prices, it requires certain caveats. Other factors that could affect prices include non-OPEC production levels for a common price path and the response of supplies and demands to price changes. For example, oil demands in HOMS-1 are much more sensitive to price increases than they are in Gately, at least for the range of prices below $\$ 55$ (1990\$), the 1981 peak. This factor places less upward pressure on prices in HOMS-1 and greater upward pressure on prices in Gately, as revealed in the bottom panel of Figure 11.

21. The Gately model used a production path that was selected on the basis of OPEC's net income position rather than an explicit capacity constraint.

22. Despite their apparent similarity, there is an important distinction between autonomous efficiency improvement and initial momentum. Oil demand reductions achieved through autonomous efficiency improvement arc costless to the economy; other inputs are not required to substitute for the lower levels of oil use. Oil demand 
reductions achieved through initial momentum (when current prices are high relative to past prices) do require the substitution of other inputs. The latter adjustments must be price induced, although the required price changes occur before the current year.

23. It appears appropriate to include these sources of oil demand changes in the initial momentum rather than the autonomous efficiency improvement effect, given the discussion in the previous endnote. The interfuel substitution effect is induced by a price change. While regulations do not explicitly raise prices, they implicitly raise the costs of oil use. Neither effect implies a costless shift towards less oil use.

24. See the appendix.

25. OECD demand grows to about 46 MMBD in WOMS.

26. Many of these models base some of their judgmental parameters, e.g., the response to price, upon statistical studies of past oil demand. However, in contrast to the first group of models, they do not derive all key parameters simultaneously from the same historical data set.

27. This conclusion is based upon standard deviations computed for each effect, excluding the alternative HOMS-1 results and setting the momentum effects for BP America and IPE to zero. As discussed later, the momentum effect for these two models is not due to incomplete adjustments to current and past prices. The GNP effects depend, of course, partly on the OECD economic growth rate (2.6\% per annum); the variation in this effect among models will be greater for faster economic growth and less for slower economic growth.

28. Similar results hold for the decomposition of OECD oil demand growth between 1988 and 1995, although the relative importance of initial momentum decreases over time.

29. HOMS-1 does the same, except that in estimating the response to prices from historical experience, it allows for a one-time shift in oil intensity after 1980.

30. This estimate includes both OECD and non-OECD countries.

31. Not all models embrace the assumption of reversibility in the demand response to price changes. The Gately model is most explicit about assumed asymmetries in the demand response to price changes. Due to large capital costs, investment in energyconservation measures is not undone when prices fall from previously high levels, so that demand would not increase very much. Nor does such investment need to be added back when prices begin to recover and rise again, so that demand would not decline very much. Indeed, the price effect for this model is relatively low, as seen from Figure 13. However, if prices were to exceed their historical maximum (which are not reached in the EMF scenarios), the price response would increase as new opportunities for investment in conservation would emerge. 
International Oil Supplies and Demands

\section{REFERENCES}

Adelman, Morris, "The Competitive Floor to World Oil Prices," The Energy Journal, 1986, Vol.7, No. 4, pp. 9-31.

Energy Information Administration, "International Energy Outlook: 1989," U.S. Department of Energy, Washington, D.C., DOE/EIA-0484(89), March 1989.

Energy Modeling Forum, "Macroeconomic Impacts of Energy Shocks," Report 7, Stanford University, Stanford, CA, in Hickman, B.G., H.G. Huntington, and J.L. Sweeney, Macroeconomic Impacts of Energy Shocks, Amsterdam: North Holland Press, 1987.

Energy Modeling Forum, "World Oil," EMF Report 6, Stanford University, Stanford, CA, 1981.

Gately, Dermot, "A Ten-Year Retrospective: OPEC and the World Oil Market", Journal of Economic Literature, 1984, Vol. 22, pp. 1100-14.

Gately, Dermot, "Lessons from the 1986 Oil Price Collapse," Brookings Papers on Economic Activity, 2:1986, pp. 237-271.

Huntington, Hillard, Andrea Kress, and Douglas Robinson, "EMF 11 Revised Scenario Design," Energy Modeling Forum, Stanford University, Stanford, CA, November 1989, in International Oil Supplies and Demand, Energy Modeling Forum, Vol. 2, forthcoming.

Huntington, Hillard G., "Inferred Price Elasticitics of Oil Supplies and Demands from a Comparison of World Oil Models," Energy Modeling Forum, Stanford University, Stanford, CA, January 1991, in International Energy Modelling, edited by Thomas Sterner, London: Chapman \& Hall, forthooming.

Kress, Andrea, Douglas Robinson, and Kenneth Ellis, "Comparison of the Structure of International Oil Models," Energy Modeling Forum, Stanford University, Stanford, CA, December 1990, in International Oil Supplies and Demand, Energy Modeling Forum, Vol. 2 , forthcoming.

Lynch, Michael C., Crude Oil Prices to 2000: The Economics of the Oil Market, Economist Intelligence Unit, 1989.

Lynch, Michael C., "Oil Capacity Costs and Prices in the 1990k," Washington International Energy Group Monograph, July 1990.

Manne, Alan S., and Leo Schrattenholzer, "The International Energy Workshop: A Progress Report," OPEC Review, Winter 1989, pp. 415-428.

Manne, Alan S., and Leo Schrattenholzer, "International Energy Workshop: Overview of Poll Responses," International Energy Project (Dept. of Operations Research), Stanford University, Stanford, CA, July 1990. 


$$
\begin{gathered}
\text { DATE } \\
\text { FILMED } \\
2 / 12 / 93
\end{gathered}
$$




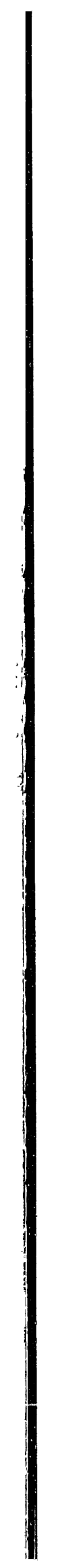

